\title{
Fordin: A novel type I ribosome inactivating protein from Vernicia fordii modulates multiple signaling cascades leading to anti-invasive and pro-apoptotic effects in cancer cells in vitro
}

\author{
WEILI LU ${ }^{1-3}$, YINGJI MAO ${ }^{1,2,4}$, XUE CHEN $^{1,2}$, JUN NI $^{1,2}$, RUI ZHANG $^{1,2}$, \\ YUTING WANG $^{1,2,5}$, JUN WANG ${ }^{1,2}$ and LIFANG WU ${ }^{1,2}$
}

\begin{abstract}
${ }^{1}$ Key Laboratory of High Magnetic Field and Ion Beam Physical Biology, Hefei Institutes of Physical Science, Chinese Academy of Sciences, Hefei, Anhui 230031; ${ }^{2}$ Institute of Technical Biology and Agriculture Engineering, Science Island Branch of Graduate School, University of Science and Technology of China, Hefei, Anhui 230026;

${ }^{3}$ Anhui Key Laboratory of Bioactivity of Natural Products, School of Pharmacy, Anhui Medical University, Hefei, Anhui 230032; ${ }^{4}$ Department of Life Sciences, Bengbu Medical College, Bengbu, Anhui, 233030;

${ }^{5}$ The Sericultural Research Institute, Anhui Academy of Agricultural Science, Hefei, Anhui, 230061, P.R. China
\end{abstract}

Received January 25, 2018; Accepted June 18, 2018

DOI: $10.3892 /$ ijo.2018.4470

\begin{abstract}
Fordin, which is derived from Vernicia fordii, is a novel type I ribosome inactivating protein (RIP) with RNA N-glycosidase activity. In the present study, fordin was expressed by Escherichia coli and purified using nickel affinity chromatography. Previous studies have demonstrated RIP toxicity in a variety of cancer cell lines. To understand the therapeutic potential of fordin on tumors, the present study investigated the effects of fordin on the viability of several tumor and normal cell lines. The results demonstrated that fordin induced significant cytotoxicity in four cancer cell lines, compared with the normal cell line. Specifically, profound apoptosis and inhibition of cell invasion were observed following fordin exposure in U-2 OS and HepG2 cells; however, the molecular mechanism underlying the action of RIP remains to be fully elucidated. In the present study, it was found that the anticancer effects of fordin were associated with suppression of the nuclear factor (NF)- $\mathrm{kB}$ signaling pathway. In U-2 OS and HepG2 cells, fordin inhibited the expression of inhibitor of NF- $\mathrm{kB}$ (IкB) kinase, leading to downregulation of the phosphorylation level of IKB, which quelled the nuclear translocation of NF- $\mathrm{kB}$. Fordin also reduced the mRNA and protein levels of NF- $\mathrm{KB}$ downstream
\end{abstract}

Correspondence to: Professor Lifang Wu or Professor Jun Wang, Key Laboratory of High Magnetic Field and Ion Beam Physical Biology, Hefei Institutes of Physical Science, Chinese Academy of Sciences, 350 Shushanhu Road, Hefei, Anhui 230031, P.R. China

E-mail:1fwu@ipp.ac.cn

E-mail: wangjun0457@ipp.ac.cn

Key words: Vernicia fordii, fordin, ribosome inactivating protein, nuclear factor- $\kappa \mathrm{B}$, apoptosis, invasion targets associated with cell apoptosis and metastasis, particularly B-cell lymphoma-2-related protein A1 (Blf-1) and matrix metalloproteinase (MMP)-9. The inactivation of NF- $\kappa \mathrm{B}$ and the reduction in the expression levels of Blf-1 and MMP-9 mediated by fordin were also confirmed by co-treatment with lipopolysaccharide or p65 small interfering RNA. These findings suggested a possible mechanism for the fordin-induced effect on tumor cell death and metastasis. The results of the present study demonstrated the multiple anticancer effects of fordin in U-2 OS and HepG2 cells, in part by inhibiting activation of the $\mathrm{NF}-\kappa \mathrm{B}$ signaling pathway.

\section{Introduction}

Ribosome-inactivating proteins (RIPs), which are widely distributed among plants, fungi, algae and bacteria, inhibit protein synthesis by irreversibly damaging ribosomes, which in turn leads to cell death $(1,2)$. RIPs are classified into three types based on structural features. Type I RIPs, including trichosanthin (TCS), saporin and curcin, are comprised of a single A-chain with RNA N-glycosidase activity (3-6). Type II RIPs are comprised of an A-chain linked to a lectin B-chain by a disulphide bond, the most well-known of which is ricin (7). Type III RIPs are considered to be pro-RIPs, which require proteolytic cleavage to become active proteins (8). In the last 10 years, RIPs, including momordica (exhibiting antihuman immunodeficiency virus activity) (9), TCS, saporin, curcin and Abrus agglutinin (exhibiting anti-neoplastic activity) $(5,6,10,11)$, have been shown to offer potential as therapeutic agents in medicine based on their biological activities.

Vernicia fordii, which belongs to the Euphorbiaceae family, is widely distributed in tropical and sub-tropical regions of Asia. The leaves, roots and seeds of $V$. fordii have been used as a traditional Chinese drug owing to its anti-inflammatory and antiviral effects (12). Based on previous literature, bioactive compounds with low molecular weights, including $\alpha$-eleostearic acid, exhibiting anti-inflammatory activity (13), 
and conjugated linoleic acid, exhibiting cytotoxic (14) and hypoglycemic activity (15), have been extracted from $V$. fordii; however, the bioactive protein from this plant remains to be fully elucidated. In our previous study, the transcriptome of $V$. fordii was sequenced to better understand the molecular basis underlying the development of the $V$. fordii bioactive protein (16). Based on the transcriptome analysis, presence of the RIP gene was confirmed in $V$. fordii. A number of RIP-containing plants are reported in the pharmacopoeia of folk medicine, mostly owing to their toxicity (17). The presence of RIP may contribute to this activity. In the present study, fordin, a novel type I RIP, was identified from $V$. fordii. The antitumor activity of fordin was evaluated in vitro by determining its cytotoxicity against human tumor cell lines (U-2 OS, HepG2, HeLa and A549) and the normal MRC-5 cell line. Although the anticancer potential of RIPs has been investigated by various groups (18-20), the mechanism underlying RIP cytotoxicity remains to be elucidated. Numerous studies have reported that RIPs exert anticancer activities by inhibiting survival and inducing apoptosis in cancer cells $(4,10,21)$. In the present study, it was shown that fordin also inhibited the invasion and migration of U-2 OS and HepG2 cells.

Nuclear factor (NF)- $\mathrm{\kappa B}$ consists of dimers containing five members of the Rel protein family (p65, p50/p105, p52/p100, Rel B and c-Rel). Inactivated NF- $\kappa \mathrm{B}$ is sequestered in the cytosol

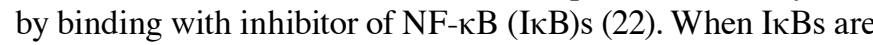
phosphorylated by the IкB kinase (IKK) complex, activated $\mathrm{NF}-\mathrm{KB}$ is released and translocated into the nucleus to modulate the expression of several genes involved in processes including cell growth and cell death (22). It is reported that NF- $\kappa B$ is key in regulation of the B-cell lymphoma-2 (Bcl-2) (23-25) and matrix metalloproteinase (MMP) (26) families, both of which have been confirmed to be important in cell apoptosis and invasion. It has also been reported that RIPs induce apoptosis in cancer cells via the downregulation of anti-apoptotic proteins, including Bcl-2 and/or Bcl-extra large (Bcl-xL) and/or the upregulation of pro-apoptotic proteins, including Bcl-2-associated X protein (Bax) and/or Bcl-2-associated death promoter $(\mathrm{Bad})(4,21)$. In this regard, it is important to clarify the role of NF- $\mathrm{KB}$ in the multiple anticancer effects of fordin.

In the present study, the effects of fordin on cell proliferation, apoptosis, invasion and migration were investigated. In addition, changes in the expression of key proteins relevant to apoptosis and metastasis in U-2 OS and HepG2 cells were determined in an effort to better understand the molecular mechanisms underlying the multiple anticancer effects of fordin in cancer cells.

\section{Materials and methods}

Molecular cloning. Total RNA was extracted from the fresh leaves of $V$.fordii (collected from the test field at Hefei Institutes of Physical Science, Chinese Academy of Science, Hefei, China) using an E.Z.N.A. Plant RNA kit (OMEGA Biotek, Inc., Norcross, GA, USA). Subsequently, RNA samples with an optical density (OD) 260/280 wavelength ratio between 2.0 and 2.2 were used for primary cDNA synthesis with a GoScript Reverse Transcription kit (Promega Corporation, Madison, WI, USA). Specific primers were designed based on the $V$. fordii RNA-Seq database (accession no. GSE98631) to obtain
V. fordii ( $v f$ )-RIP and its mature peptide (fordin), as follows: $v f$-RIP, forward, 5'-ATTAGAAACCATCTCCTCCCTCT-3' and reverse, 5'-CTTAGTTTGAAGCCCTTCTACTT-3'; fordin, forward, 5'-AATGGATCCAGAGTTAGCCCTTTACTA-3' and reverse, 5'-GGGAAGCTTCTACTTCTTTACATACAGC-3'. The underlined bases in the primers were designated as BamHI and HindIII restriction sites, respectively. The polymerase chain reaction (PCR) was performed in 50- $\mu 1$ reaction mixtures (Takara Biotechnology Co., Ltd., Dalian, China), each mixture included: $0.5 \mu 1$ PrimeSTAR HS DNA Polymerase, $10 \mu \mathrm{l}$ 5X PCR Buffer, $4 \mu 1 \mathrm{cDNA}, 4 \mu 1 \mathrm{dNTPs}, 2 \mu \mathrm{l}$ primers, and

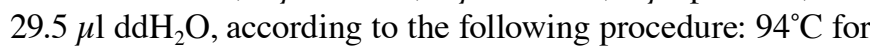
$2 \mathrm{~min} ; 30 \mathrm{cycles}$ at $98^{\circ} \mathrm{C}$ for $10 \mathrm{sec}, 58^{\circ} \mathrm{C}$ for $90 \mathrm{sec}$, and $68^{\circ} \mathrm{C}$ for $45 \mathrm{sec}$; and final extension at $68^{\circ} \mathrm{C}$ for $10 \mathrm{~min}$. The PCR products were analyzed by $1.2 \%$ agarose electrophoresis. The fragments of expected size were purified with an Agarose Gel Extraction kit (OMEGA Biotek, Inc.), and then cloned into the pEASY-T1 vector (Beijing TransGen Biotech Co., Ltd., Beijing, China) for sequencing. Multiple sequence alignment was performed using DNAMAN software 8.0 (LynnonBiosoft Bioinformatics solutions, San Ramon, CA, USA).

Expression and purification of fordin. The coding sequence of fordin was cloned into the pET28b-SUMO vector, constructed by Professor Fan (University of Anhui Agriculture, Anhui, China) $(27,28)$. The recombinant plasmid (pSUMO-Fordin) was transformed into Escherichia coli Rosetta host strain (DE3) competent cells (Novagen/Merck, Darmstadt, Germany). E. coli harboring the recombinant plasmid was incubated with shaking at $200 \mathrm{rpm}$ at $37^{\circ} \mathrm{C}$ until the OD 600 of the culture reached 0.8 . The expression of SUMO-Fordin was induced by the addition of $0.5 \mathrm{mM}$ IPTG. Following further incubation at $16^{\circ} \mathrm{C}$ for $24 \mathrm{~h}$, the cells were harvested and sonicated in binding buffer containing $50 \mathrm{mM} \mathrm{NaH}_{2} \mathrm{PO}_{4}(\mathrm{pH} 8.0)$ and $300 \mathrm{mM}$ $\mathrm{NaCl}$. The cell-free supernatant was applied to a $\mathrm{Ni}^{2+}$ resin column $(2.0 \times 15 \mathrm{~cm})$. The resin was washed with the binding and washing buffers, containing $50 \mathrm{mM} \mathrm{NaH}_{2} \mathrm{PO}_{4},(\mathrm{pH} 8.0)$, $300 \mathrm{mM} \mathrm{NaCl}$, and $20 \mathrm{mM}$ imidazole. The fusion protein was eluted with elution buffer containing $50 \mathrm{mM} \mathrm{NaH}_{2} \mathrm{PO}_{4}(\mathrm{pH} 8.0)$, $300 \mathrm{mM} \mathrm{NaCl}$ and $250 \mathrm{mM}$ imidazole. To cleave the His-SUMO tag by protease ULP, the fusion protein was then processed with buffer through ultrafiltration columns (EMD Millipore, Billerica, MA, USA) with membrane cartridges having molecular weight cut-offs of 3,000 Da. The cleaved protein (fordin) was purified by $\mathrm{Ni}^{2+}$ resin again. Finally, fordin was pooled and measured using a BCA protein assay kit (Sangon Biotech Co., Ltd., Shanghai, China). The purity of fordin was analyzed by $12 \%$ sodium dodecyl sulfate-polyacrylamide gel electrophoresis (SDS-PAGE). Western blot analysis using rabbit polyclonal antibodies specific for 6X His-tag (1:1000, cat. no. D110002; Sangon Biotech Co., Ltd.) was performed to confirm the presence of the fusion protein. The identification of fordin was assessed by liquid chromatography-mass spectrometry with a MALDI TOF/TOF analyzer (ABI; Thermo Fisher Scientific, Inc., Waltham, MA, USA).

RNA N-glycosidase activity assay. The assay was performed according to the method described by Wu et al (29) with several revisions. Total RNA was extracted from Sapium sebiferum leaves (collected from the test field at Hefei Institutes of Physical 
Table I. Nucleotide sequences of the primers for reverse transcription-quantitative polymerase chain reaction analysis.

\begin{tabular}{lllr}
\hline Gene & \multicolumn{1}{c}{$\begin{array}{c}\text { Forward primer } \\
\left(5^{\prime}-3^{\prime}\right)\end{array}$} & \multicolumn{1}{c}{$\begin{array}{c}\text { Reverse primer } \\
\left(5^{\prime}-3^{\prime}\right)\end{array}$} & $\begin{array}{c}\text { Amplification } \\
\text { length (bp) }\end{array}$ \\
\hline Bcl-2 & CGGTGGGGTCATGTGTGTG & CGGTTCAGGTACTCAGTCATCC & 90 \\
Bax & TCATGGGCTGGACATTGGAC & GAGACAGGGACATCAGTCGC & 114 \\
Bfl-1 & TACAGGCTGGCTCAGGACTAT & CGCAACATTTTTAGCACTCTG & 96 \\
Bcl-xL & GAGCTGGTGGTTGACTTTCTC & TCCATCTCCGATTCAGTCCCT & 138 \\
MMP-2 & AGGGAATGAATACTGGATCTACT & GCTCCAGTTAAAGGCGGCATCCAC & 119 \\
MMP-9 & GGGACGCAGACATCGTCATC & TCGTCATCGTCGAAATGGGC & 139 \\
Timp-3 & ACCGAGGCTTCACCAAGATG & GGGGTCTGTGGCATTGATGA & 125 \\
uPA & TCAAAAACCTGCTATGAGGGGA & GGGCATGGTACGTTTGCTG & 121 \\
uPAR & TATTCCCGAAGCCGTTACCTC & TCGTTGCATTTGGTGGTGTTG & 275 \\
Cathepsin B & CTGTCGGATGAGCTGGTCAAC & TCGGTAAACATAACTCTCTGGGG & 152 \\
IKK $\alpha$ & AAGTTGAACCATGCCAATGTTGT & TCTCCTCCAGAACAGTATTCCAT & 107 \\
IKK $\beta$ & CACCATCCACACCTACCCTG & CTTATCGGGGATCAACGCCAG & 136 \\
NEMO & CTTCCAAGAATACGACAACCACA & CGGAACGGTCTCCATCACAAT & 187 \\
GAPDH & GCACCGTCAAGGCTGAGAAC & TGGTGAAGACGCCAGTGGA & 138 \\
\hline
\end{tabular}

Bcl-2, B-cell lymphoma-2; Bax, B-cell lymphoma-2-associated X protein; Bfl-1, B-cell lymphoma-2-related protein A1; MMP, matrix metalloproteinase; Timp-3, tissue inhibitor of metalloproteinase; IKK, inhibitor of nuclear factor- $\mathrm{KB}$ kinase.

Science) by the method mentioned above. Subsequently, $3 \mu \mathrm{g}$ total RNA was treated with $0.4 \mu \mathrm{g}$ of fordin. The mixture was incubated at $30^{\circ} \mathrm{C}$ for $30 \mathrm{~min}$, and then treated with $2 \mathrm{M}$ fresh aniline/acetate ( $\mathrm{pH} 4.5)$. RNA was recovered by ethanol precipitation and examined by $2.0 \%$ agarose electrophoresis.

Cell culture. Human osteosarcoma (U-2 OS), hepatoblastoma (HepG2) (30), cervical carcinoma (HeLa), lung carcinoma (A549) and fetal lung fibroblast (MRC-5) cell lines were purchased from the American Type Culture Collection (Manassas, VA, USA) and cultured in DME/F-12 medium (GE Healthcare Life Sciences, Logan, UT, USA) supplemented with $10 \%$ fetal bovine serum (FBS; BioWest, Miami, FL, USA). The cells were incubated in a humidified atmosphere with $5 \% \mathrm{CO}_{2}$ at $37^{\circ} \mathrm{C}$.

Cell viability assay. The cell viability was assessed using a Cell Counting Kit-8 (CCK-8) assay (Sangon Biotech, Co., Ltd.). The cell suspension $(100 \mu \mathrm{l})$ was dispensed $\left(7 \times 10^{3}\right.$ cells/well) into 96-well plates and exposed to various concentrations of fordin $(0.2-10 \mu \mathrm{M})$ for 24,48 and $72 \mathrm{~h}$. CCK-8 solution was added ( $10 \mu \mathrm{l} / \mathrm{well})$ and incubated for $30 \mathrm{~min}$. The absorbance was measured at $450 \mathrm{~nm}$ using a microplate reader (Molecular Devices LLC, Sunnyvale, CA, USA). Cell viability was calculated as the percentage of untreated controls. Inhibitory concentrations (ICs) of fordin were calculated using SPSS 16.0 software (SPSS, Inc., Chicago, IL, USA). In a subsequent experiment, to avoid antiproliferative effects, relatively low concentrations of fordin $\left(1 \mu \mathrm{M}\right.$ and $\left.\mathrm{IC}_{20}\right)$ were used for investigating the scratch-healing and invasive behavior of U-2 OS and HepG2 cells. Low $\left(\mathrm{IC}_{20}\right)$, medium $\left(\mathrm{IC}_{50}\right)$, and high $\left(\mathrm{IC}_{70}\right)$ fordin concentrations were used to evaluate concentrationdependent effects on U-2 OS and HepG2 cells via nuclear staining, flow cytometry, and reverse transcription-quantitative PCR (RT-qPCR) and western blot analyses.
Scratch assay. The U-2 OS and HepG2 cells were seeded into 6-well plates. The confluent monolayers of cells were scratched using $200-\mu 1$ sterile pipette tips. Following removal of the floating cells, the cells were cultured in medium without serum. The effect of fordin $\left(1 \mu \mathrm{M}\right.$ and $\left.\mathrm{IC}_{20}\right)$ on the scratch-healing response was determined under an inverted microscope (Olympus, Tokyo, Japan). A total of six randomly selected images were selected per sample at 0 and $24 \mathrm{~h}$.

Cell invasion assay. The effect of fordin on cell invasion ability was investigated using a Transwell assay. Matrigel (BD Biosciences, Franklin Lakes, NJ, USA) diluted 1:8 in cold serum-free culture media was added to each 24-well Transwell chamber with an $8-\mu \mathrm{m}$ pore polycarbonate membrane (Corning Incorporated, Corning, NY, USA) and incubated under standard conditions for at least $12 \mathrm{~h}$ to gel. The cells treated with fordin $\left(1 \mu \mathrm{M}\right.$ and $\left.\mathrm{IC}_{20}\right)$ for 24 and $48 \mathrm{~h}$ were seeded onto the Matrigel. Each lower chamber contained $600 \mu 1$ of culture media containing 10\% FBS. Following incubation for $24 \mathrm{~h}$, transmembrane cells were stained by $0.1 \%$ crystal violet. Six fields were randomly selected under the inverted fluorescence microscope, and the number of transmembrane cells was counted.

Nuclear staining. The selected cells were seeded into 12-well plates containing sterilized coverslips. Following treatment with fordin $\left(\mathrm{IC}_{20}, \mathrm{IC}_{50}\right.$, or $\left.\mathrm{IC}_{70}\right)$ for $24 \mathrm{~h}$, the cells were fixed with $4 \%$ paraformaldehyde, and stained with $4 \mu \mathrm{g} / \mathrm{ml}$ of Hoechst 33342 solution (Invitrogen; Thermo Fisher Scientific, Inc.). The coverslips with cells were inverted onto slides. Six random images were captured with the inverted fluorescent microscope.

Annexin V/propidium iodide (PI) analysis. Following treatment with fordin $\left(\mathrm{IC}_{20}, \mathrm{IC}_{50}\right.$, or $\left.\mathrm{IC}_{70}\right)$ for $24 \mathrm{~h}$, the U-2 OS and HepG2 
cells were harvested, and the extent of apoptosis was determined through flow cytometry using an Annexin V-FITC/Dead Cell Apoptosis kit (Invitrogen; Thermo Fisher Scientific, Inc.) according to the manufacturer's protocol. Cell apoptosis was analyzed in triplicate for each treatment using a FACSCalibur platform (BD Biosciences) and FlowJo software 7.6 (Tree Star, Inc., Ashland, OR, USA).

Small interfering (si)RNA transfection. NF- $\kappa \mathrm{B} / \mathrm{p} 65$ siRNA was purchased from GenePharma (Shanghai, China). Non-silencing siRNA was used as the negative control. U-2 OS and HepG2 cells were transfected with p65 siRNA or control siRNA using Lipofectamine 2000 (Invitrogen; Thermo Fisher Scientific, Inc.) for $48 \mathrm{~h}$ according to the manufacturer' $\mathrm{s}$ protocol. Following transfection, the cells were treated with or without fordin $\left(\mathrm{IC}_{50}\right)$ for $24 \mathrm{~h}$. Subsequently, certain proteins involved in the $\mathrm{NF}-\kappa \mathrm{B}$ signaling pathway were analyzed by western blot analysis.

RT-qPCR analysis. Total RNA was extracted using the E.Z.N.A RNA kit from cells treated with fordin $\left(\mathrm{IC}_{20}, \mathrm{IC}_{50}\right.$, or $\left.\mathrm{IC}_{70}\right)$ for $24 \mathrm{~h}$. cDNA corresponding to $1 \mu \mathrm{g}$ of total RNA was used to examine the mRNA levels of the selected genes by a Light Cycler 96 Real-Time PCR system (Roche Diagnostics GmbH, Mannheim, Germany). FastStart Essential DNA Green Master mix (Roche Diagnostics GmbH) was applied for the RT-qPCR analysis. Each reaction mixture included $10 \mu 12 x$ Master Mix,

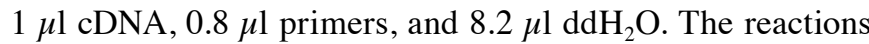
were performed according to the following conditions: $94^{\circ} \mathrm{C}$ for $30 \mathrm{sec}, 40$ cycles at $94^{\circ} \mathrm{C}$ for $5 \mathrm{sec}$, the optimal temperature for primers of the selected genes (Table I) for $15 \mathrm{sec}$ and $72^{\circ} \mathrm{C}$ for $10 \mathrm{sec}$. After 40 cycles, the dissociation curve was determined. All samples were performed as triplicate. The $2^{-\Delta \Delta \mathrm{Cq}}$ method (31) was applied to calculate the relative mRNA expression of the selected genes using GAPDH to normalize the data.

Western blot analysis. Following the various treatments, the cells were maintained in lysis buffer for $10 \mathrm{~min}$ on ice for preparing the whole cell lysates. Nuclear and cytoplasmic extracts were prepared using NE-PER ${ }^{\mathrm{TM}}$ nuclear and cytoplasmic extraction reagents (Thermo Fisher Scientific, Inc.) according to the manufacturer's protocol. The protein concentrations were measured using a BCA Protein Assay kit. Equal quantities $(50 \mu \mathrm{g})$ of protein were separated on a $12 \%$ SDS-PAGE gel and then transferred onto a PVDF membrane (EMD Millipore), which was then blocked in $5 \%$ skim milk for $1 \mathrm{~h}$ at room temperature. The membrane was then incubated overnight with primary antibodies at $4^{\circ} \mathrm{C}$. The primary antibodies were as follows: Anti-Bcl-2-associated $\mathrm{X}$ protein (Bax; 1:2,000, cat. no. sc-70408) and anti-Bcl-2 (1:1,000, cat. no. sc-130308) from Santa Cruz Biotechnology, Inc. (Dallas, TX, USA). The other primary antibodies were anti-Bcl-2-related protein A1 (Bfl-1; 1:200, cat. no. ab45413), anti-MMP-2 (1:500, cat. no. ab92536), anti-MMP-9 (1:500, cat. no. ab76003), anti-p65 [(phosphorylated S536; 1:1,000, cat. no. ab76302) and total (1:1,000, cat. no. ab76311)], anti-IKK $\alpha$ (1:1,000, cat. no. ab32518), anti-IKK $\beta$ (1:1,000, cat. no. ab124957), and anti-IкB [(phosphorylated S36; 1:1,000, cat. no. ab133462) and total (1:1,000, cat. no. ab32518)], all of which were purchased from Abcam (Cambridge, MA, USA). The membrane was incubated with the secondary antibody (goat anti-mouse IgG-HRP, 1:1,000, cat. no. sc-2005; goat anti-rabbit IgG-HRP, 1:1,000, cat. no. sc-2004; Santa Cruz Biotechnology, Inc.) for $2 \mathrm{~h}$ at room temperature and visualized by chemiluminescence. $\beta$-actin and Histone $\mathrm{H} 3$ were used as internal controls for the whole cell lysates, cytosolic extracts and nuclear extracts, respectively.

Statistical analysis. The statistical analysis was performed using GraphPad Prism 6 software (GraphPad Software, Inc., La Jola CA, USA). All data are expressed as the mean \pm standard deviation. Statistical analysis between groups was performed by one-way analysis of variance followed by the LSD post hoc test. $\mathrm{P}<0.05$ was considered to indicate a statistically significant difference.

\section{Results}

Molecular cloning and expression of fordin. The coding sequence of the $v f$-RIP gene (GenBank accession no. MF521485) is $840 \mathrm{bp}$ in length with translation initiation (ATG) and stop (TAG) codons. The open reading frame encodes a 279-amino acid polypeptide, of which the putative molecular mass is $30.8 \mathrm{kDa}$. An endoplasmic reticulum signal peptide (residues 1-21) was identified, followed by the mature peptide (fordin; residues 22-279) with a molecular mass of $28.3 \mathrm{kDa}$ (Fig. 1). The results of sequence alignment showed that fordin showed similarity with other type I RIPs, including TCS (from Trichosanthes kirilowi), curcin (from Jatropha curcas), momorcharin (from Momordica charantia) and ricin A-chain (from Ricinus communis) with respect to the conserved region. The fordin amino acid residues, Tyr-109 (Y), Tyr-148 (Y), Glu-197 (E), Arg-200 (R), and Trp-229 (W), aligned perfectly with the consensus active site sequences of RIPs (Fig. 1) (32).

$E$. coli strains harboring the recombinant plasmid (pSUMO-Fordin) and non-recombinant plasmid (pSUMO) were incubated for expression analysis. The recombinant protein with an expected band of $\sim 45 \mathrm{kDa}$ was detected in the soluble fraction (Fig. 2A), which consisted of the SUMO protein with a molecular weight of $20 \mathrm{kDa}$ fused to fordin. The His-SUMO tag allowed the fused protein to be purified by Ni-NTA affinity chromatography and be confirmed by western blot analysis using the rabbit polyclonal anti-His antibody (Fig. 2B). The His-SUMO tag was cleaved with protease ULP, and fordin was measured. The purity of the fused protein and fordin was identified via the presence of a single band at $\sim 45$ and $28 \mathrm{kDa}$ on the gel, respectively (Fig. 2A). The yields of the fused protein and fordin were $\sim 25$ and $13 \mathrm{mg}$ of protein/1 of bacterial culture, respectively. The expressed protein was characterized by mass spectrometry (MS) analysis, and the theoretical molecular mass obtained by MS methods was $28.3 \mathrm{kDa}$. The sequence from MS analysis had 54\% sequence identity with the putative polypeptide based on the $v f$-RIP gene, with 21 unique matching peptides (partially in Table II).

The N-glycosidase activity of fordin was examined against Sapium sebiferum rRNA. A specific endo-fragment was generated following fordin treatment due to the $\mathrm{N}$-glycosidase activity of fordin (Fig. 2C). The negative control (no fordin treatment), did not yield the same fragment. 


\begin{tabular}{|c|c|c|}
\hline & signal & \\
\hline Fordin & NKVWVVVIATKEWINITFGSARVSPIIAN.DLHHN & 34 \\
\hline trichosanthin & $\ldots \ldots \ldots \ldots$ NIRFLVISLIILTLFL & 16 \\
\hline curcin & MKGGKMNLSIMVAAWFCWSSIIFGWASAREIVCFFSSNQN & 40 \\
\hline Ricin_A_chain & .....NKPGGNTIVIKMYAVATWLCFGSTSGWSFTLEDNN & 35 \\
\hline $\begin{array}{l}\text { alpha-momorcharin } \\
\text { Consensus }\end{array}$ & .NSRESVISFIIIAIFL & 16 \\
\hline Fordin & ISETTTQGATN.SSŸSTELLSIRIAVK. . SGNS & 71 \\
\hline trichosanthin & TTEAVEGDVSFRISGATS.SSYGGVEISNIA KALEN.ERKL & 54 \\
\hline curcin & YKAGSTPTIAITYLATTDKKN』AQEIELIREAFLF.SYLS & 79 \\
\hline Ricin_A_chain & IFFKQYPIINETTAGATV.QSYYTNEIRAVRGRLTTGADVR & 74 \\
\hline alpha-momorcharin & GGSIVKGDVSERISGADP.RSI & 54 \\
\hline Consensus & $\mathrm{fi} r \mathrm{a}$ & \\
\hline Fordin & ST. C. CAKDVTIGLNVINL & 108 \\
\hline trichosan & CRYYALVHLTAYALETISVAIDVTSV & 92 \\
\hline curcin & HKIFVIR . . ATVAANÇKF IVAKVIINSGLIEVSVGLNVINA & 117 \\
\hline Ricin_A_chain & HE IFVIPNRVGLEINÇRF ILVELSN̈HAELSVTIALDVTTNA & 114 \\
\hline alpha-momo & AGRYIIMHLEMYDGKTITVAVDVTNV & 92 \\
\hline Consensus & $\bar{v} \mathrm{n}$ & \\
\hline Fordin & TTYIFEGTKCุT.NLKF & 144 \\
\hline trichosanthin & AKYVEKIIAMRKVTLPY & 130 \\
\hline curcin & YKVGSNSYFFNLSESL. ADAKKNIFTETNCQ. TIAF & 155 \\
\hline Ricin_A_chain & Y VVGYFAGNSAYFHHFDNÇELAEA ITHIFTLVQNRYTFAF & 154 \\
\hline alpha-momorcharin & YIADTTSYFENEFAAEE . .IASQYVERIARRKITLPY & 130 \\
\hline Consensus & $\bar{y} \quad \bar{y} \quad g \quad s y f f$ & \\
\hline Fordin & YIINKSTKPE. & 182 \\
\hline trichosanthin & ITTIFYYNANS. & 169 \\
\hline curcin & EVDIGVVIIDNYVYIIEKSSÇEA. & 194 \\
\hline Ricin_A_chain & ŶRIEQIAGNIENIEIGNGEIEEAISZIYYYSTGGT & 194 \\
\hline alpha-momorcharin & STILHYDSTA. & 169 \\
\hline Consensus & $g y$ l a re lg al & \\
\hline Fordin & IITNEG. .C्REK & 217 \\
\hline trichosanthin & . PRSAINVIIQSTSEAR RKEIEQCIGKRVL . . KTFL & 203 \\
\hline curcin & ...DIRKPIVGFIEMVE $\bar{A} \bar{R}$ RYIEKKISTQIS. .KTFR & 229 \\
\hline Ricin_A_chain & QLETIRRSFIICICMISEAR REYIBGEMRTRIRYNRRSA & 234 \\
\hline alpha-momorcharin & 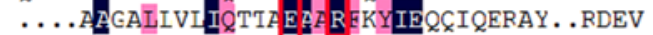 & 203 \\
\hline Consensus & a iq earf yie & \\
\hline Fordin & IAD.ANGKG & 256 \\
\hline trichosanthin & 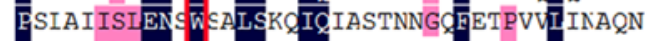 & 243 \\
\hline curcin & DI ISIENN WGDLSYCICKS . . VDDV ELKPVQIQRENY & 267 \\
\hline Ricin_A_chain & EDFSVITLENSWGRLSTAIQESN.C. GZFASPIQIQRRNG & 272 \\
\hline alpha-mon & 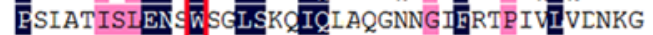 & 243 \\
\hline Consensus & $\overline{\mathrm{p}} \quad$ islen $\overline{\mathrm{w}} \overline{\mathrm{Is}} \quad \overline{\mathrm{iq}}$ & \\
\hline Fordin & TLYNISTV̄S..尺IKPIMGILLYVKK. & 279 \\
\hline trichosanthin & QRVTITNVLAGVVTSNIAILLNRNINAPMDLDVEMTC्CSFG & 283 \\
\hline curcin & TNILVNNVT ..QVKGIMGVLLNAVNYKVSMEEIIFNEQKW & 305 \\
\hline Ricin_A_chain & SKESVYDV̈S...IIIPIIAIMVYRCAPPFSSÇ. . . . . & 301 \\
\hline alpha-momorcharin & NRVQITNVTSKVVTSNIQILINTRNIAEGDNGD.VSTTHG & 282 \\
\hline Consensus & $\mathrm{v} \quad 11$ & \\
\hline Fordin & & 279 \\
\hline trichosanthin & CGSYA & 288 \\
\hline curcin & LPKLL. & 309 \\
\hline Ricin_A_chain & & 301 \\
\hline alpha-momorcharin & FSSY. & 286 \\
\hline
\end{tabular}

Figure 1. Multiple alignment of fordin with various RIPs. The amino acid sequence of signal peptide is underlined. Fordin shows strong similarity to different type I RIPs, with regard to the catalytic key residues (boxed) of the proteins. RIPs, ribosome-inactivating proteins.

Fordin inhibits viability of cancer cells. The selected tumor and normal cell lines were treated with increasing concentrations of Fordin $(0.2-10 \mu \mathrm{M})$ for 24, 48 and $72 \mathrm{~h}$. Following fordin exposure, effective cytotoxic activity was observed as a decline in survival rates in a dose- and time-dependent manner in the four cancer cell lines (Fig. 3A-D). The ICs of fordin were calculated based on the viability assay (Table III). Considering the $\mathrm{IC}_{50}$ values, fordin was more toxic against the four tumor cell lines, particularly the U-2 OS and HepG2 cells, than the normal cell line (Fig. 3E). Specifically, a sharp decline in survival was observed in the U-2 OS and HepG2 cells at a fordin concentration $>1 \mu \mathrm{M}$ at the 24 - and 48-h time intervals, as shown in Fig. 3A and B.

Fordin exposure induces apoptosis. To confirm fordin induces apoptosis, the nuclear morphology of U-2 OS, Hep G2 and 

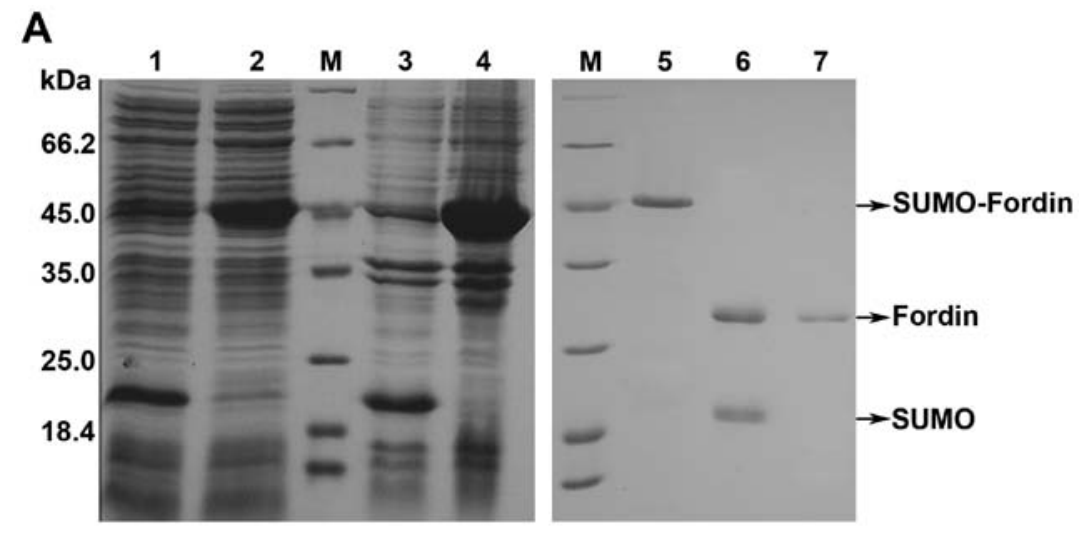

B

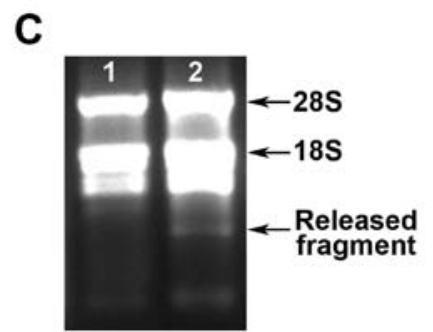

Figure 2. Expression analysis and N-glycosidase activity analysis of fordin. (A) Sodium dodecyl sulfate-polyacrylamide gel electrophoresis analysis of fordin expressed in E. coli. Lane M, protein molecular weight marker $(\mathrm{kDa})$; lane 1, supernatant of the cell lysate of Rosetta transformed with the empty vector pSUMO; lane 2, supernatant of the cell lysate of Rosetta transformed with recombinant vector pSUMO-Fordin; lane 3, inclusion bodies of Rosetta transformed with the empty vector pSUMO; lane 4, inclusion bodies of Rosetta transformed with recombinant vector pSUMO-Fordin; lane 5, purified fusion protein; lane 6, fusion protein following treatment with ULP; lane 7 purified fordin. (B) Western blot analysis using polyclonal anti-His antibodies. Lane 1, purified fusion protein; lane 2, fusion protein following treatment with ULP; lane 3, purified fordin. (C) RNA N-glycosidase activity of fordin. Lane 1, control rRNA without fordin treatment; lane 2 , rRNA treated with $0.4 \mu \mathrm{g}$ fordin.

A

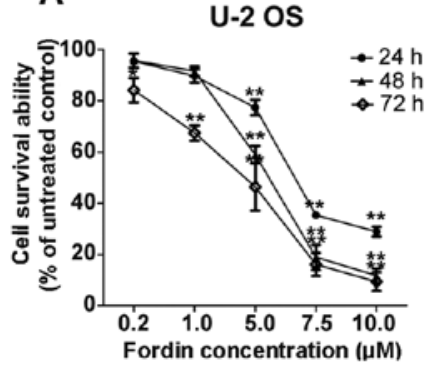

B

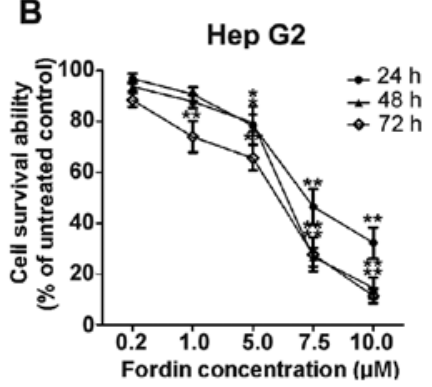

C

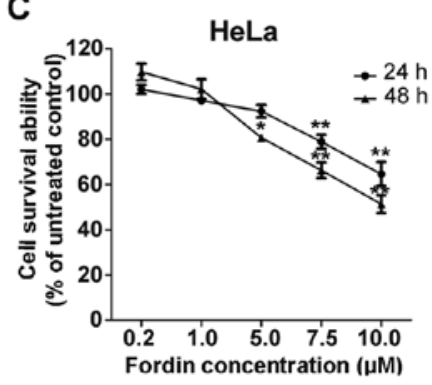

D

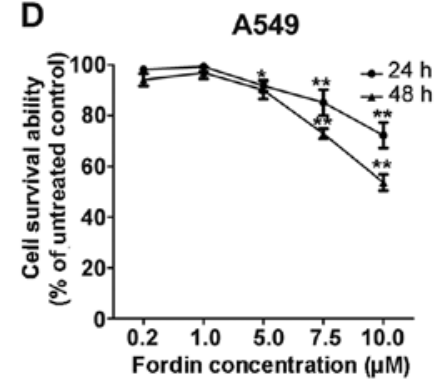

E

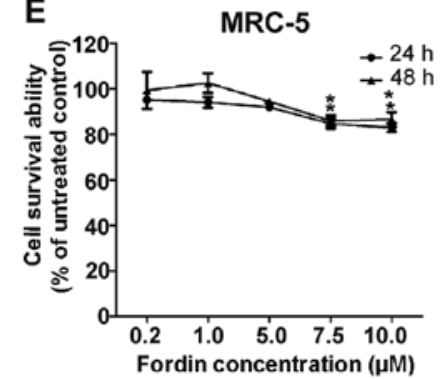

Figure 3. Cytotoxic effects of fordin determined using a Cell Counting Kit-8 assay in tumor and normal cell lines. (A) U-2 OS, (B) HepG2, (C) HeLa, (D) A549 and (E) MRC-5 cells were treated with increasing concentrations of fordin for 24, 48 and $72 \mathrm{~h}$. Values are presented as the mean \pm standard deviation of three independent experiments. ${ }^{*} \mathrm{P}<0.05$ and $^{* *} \mathrm{P}<0.001$.

MRC-5 cells was determined by Hoechst 33342 staining using fluorescence microscopy. Exposure of the cells to fordin $\left(\mathrm{IC}_{20}\right.$, $\mathrm{IC}_{50}$, or $\mathrm{IC}_{70}$ ) for $24 \mathrm{~h}$ resulted in clear destructive changes (chromatin condensation and nuclear fragmentation) in the cancer cell nuclei. At the fordin $\mathrm{IC}_{20}$, nuclear shrinkage and chromatin condensation were noted, whereas at $\mathrm{IC}_{50}$ or $\mathrm{IC}_{70}$, nuclear fragmentation was also observed in the cells (Fig. 4A). The apoptotic effects in response to fordin exposure were more profound in U-2 OS and HepG2 cells compared with MRC-5 cells (Fig. 4A and B).

To further verify fordin as an inducer of apoptosis, an Annexin V-based assay was performed. The cells treated with 


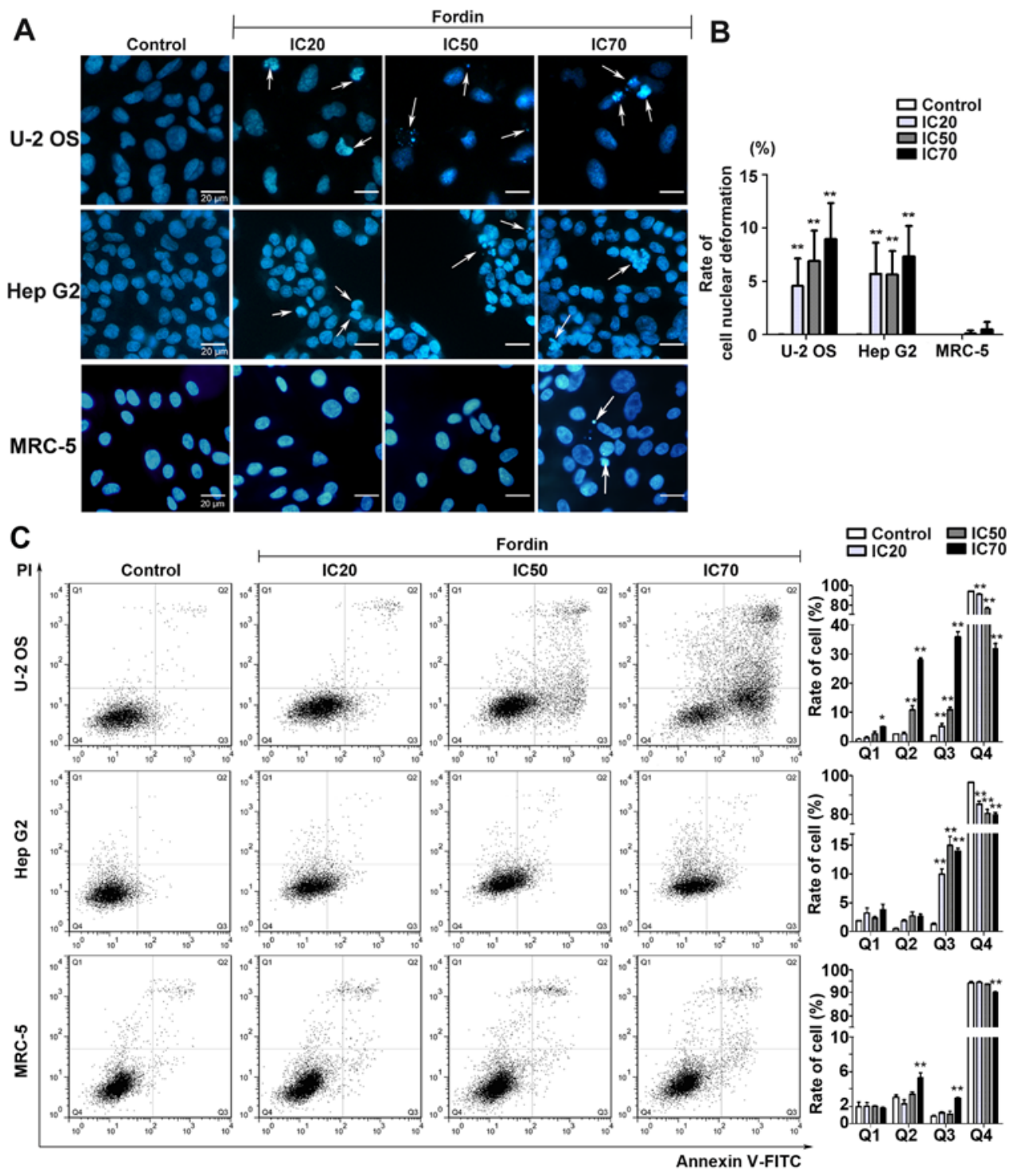

Figure 4. Apoptotic effects of fordin on U-2 OS, HepG2 and MRC-5 cells. (A) Fordin induced significant signs of apoptosis, including nuclear shrinkage, chromatin condensation and fragmentation (indicated by arrows) in cells. Magnification, x40. (B) Rates of cell nuclear deformation obtained from nuclear stain assaying demonstrated the induction of apoptosis following fordin exposure in a dose-dependent manner in cancer cells. (C) Induction of apoptosis in the selected cells by fordin exposure was determined by an Annexin V-FITC assay. ${ }^{*} \mathrm{P}<0.05$ and ${ }^{* *} \mathrm{P}<0.001$ vs. untreated control group. PI, propidium iodide; IC, inhibitory concentration.

fordin $\left(\mathrm{IC}_{20}, \mathrm{IC}_{50}\right.$, or $\left.\mathrm{IC}_{70}\right)$ for $24 \mathrm{~h}$ were examined by $\mathrm{FACS}$ analysis. Significant increases, from 2.03 to $35.65 \%$ and 1.30 to $13.95 \%$, occurred in Annexin V-FITC-positive cells with increasing concentrations of fordin in U-2 OS and HepG2 cells, respectively (Fig. 4C). However, this increase was lower (from 0.84 to $2.90 \%$ ) in the MRC-5 cells.

Following fordin treatment for $24 \mathrm{~h}$, apoptosis-related gene expression of the U-2 OS and HepG2 cells was examined by RT-qPCR and western blot analyses. The results showed the potential of fordin to influence the expression of Bcl-2 family genes (Fig. 5). Fordin exposure significantly increased the mRNA level of Bax (maximum, 2.6-fold), and inhibited the mRNA level of Bfl-1 (maximum, 46.0-fold) in U-2 OS cells. The mRNA expression levels of Bcl-2 and Bcl-xL in the treated cells were essentially unchanged compared with those in the untreated cells. Similar effects were observed in HepG2 cells, in which maximum induction was 2.7-fold for the Bax gene and maximum inhibition was 47.9-fold for the
Bfl-1 gene. These results are consistent with the western blot data. The expression of Bax was increased in a concentrationdependent manner in the U-2 OS (Fig. 5C and D) and HepG2 cells (Fig. 5E and F), with maximum increases of 2.3- and 3.1-fold, respectively $(\mathrm{P}<0.001)$. The expression of $\mathrm{Bfl}-1$ was decreased in the U-2 OS (maximum, 1.5-fold, $\mathrm{P}<0.05$ ) and HepG2 (maximum, 7.6-fold, $\mathrm{P}<0.05$ ) cells. The expression of Bcl-2 did not differ between the treated cells and untreated control cells.

Fordin treatment interferes with cell invasion and migration. The Transwell assay was used to evaluate the effects of fordin on the invasive activity of U-2 OS and HepG2 cells. The invasive behavior of the cells was examined following 24 and $48 \mathrm{~h}$ treatment with fordin $\left(1 \mu \mathrm{M}\right.$ and $\left.\mathrm{IC}_{20}\right)$. The two cell lines exhibited a reduction in the number of trans-membrane cells (Fig. 6). The number of U-2 OS cells was reduced by $23 \%(\mathrm{P}<0.05)$ and $74 \%(\mathrm{P}<0.001)$ following $24 \mathrm{~h}$ treatment 
A

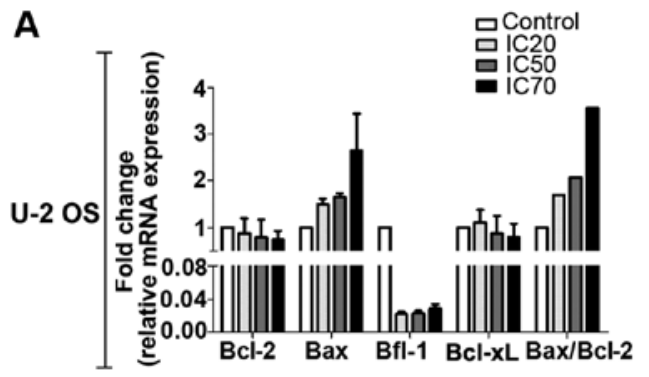

C

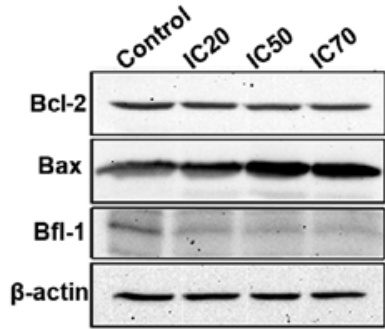

$\mathbf{E}$

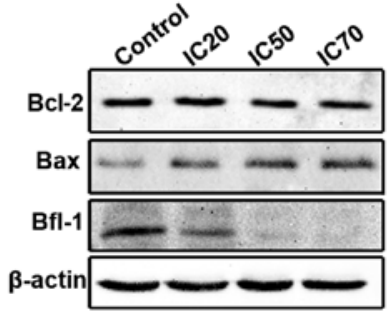

B

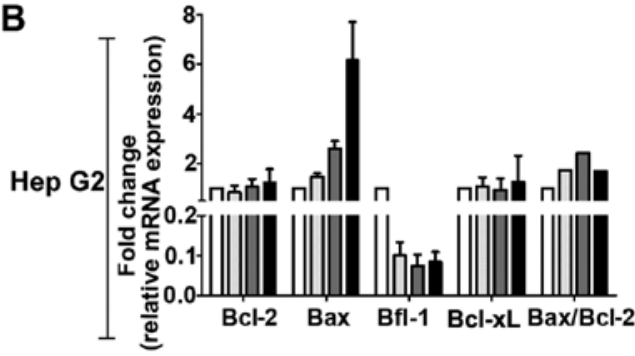

D

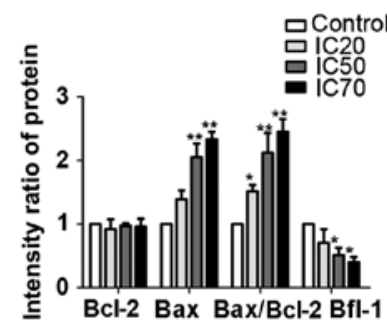

$\mathbf{F}$

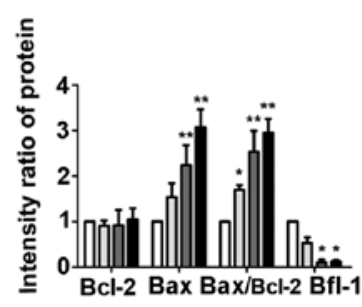

Figure 5. Effects of fordin on the expression of Bcl-2 family genes in U-2 OS and HepG2 cells. Cells were incubated with fordin (IC $\mathrm{IC}_{20}, \mathrm{IC}_{50}$ or $\left.\mathrm{IC}_{70}\right)$ for $24 \mathrm{~h}$. mRNA levels of Bcl-2 family genes were analyzed by RT-qPCR in (A) U-2 OS and (B) HepG2 cells. Protein expression levels of Bcl2, Bax and Bfl-1 were analyzed by western blot analysis and normalized to the level of $\beta$-actin. (C) Western blot and (D) quantification in U-2 OS cells; (E) western blot and (F) quantification in HepG2 cells. ${ }^{*} \mathrm{P}<0.05$ and ${ }^{* *} \mathrm{P}<0.001$ vs. untreated control group. Bcl-2, B-cell lymphoma 2; Bax, Bcl-2-associated X protein; Bfl-1, Bcl-2-related protein A1; IC, inhibitory concentration.

A
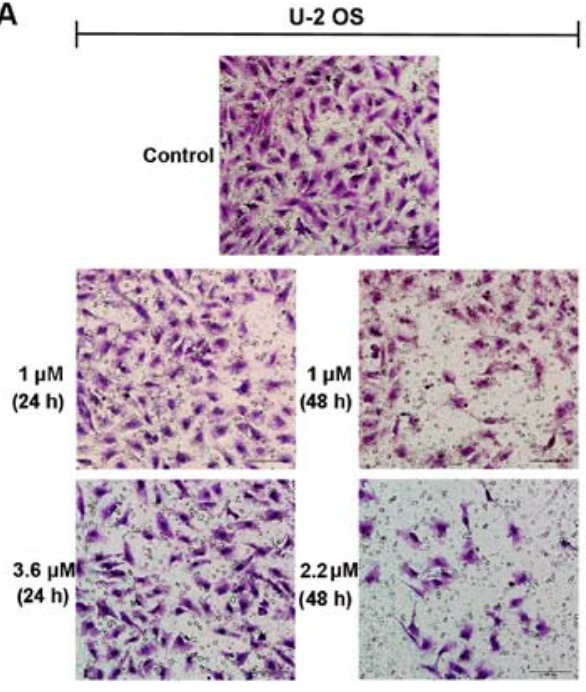

B
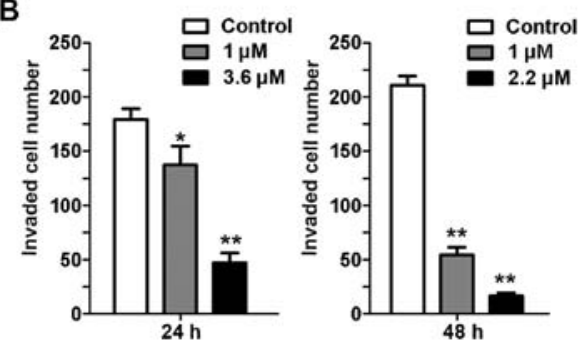
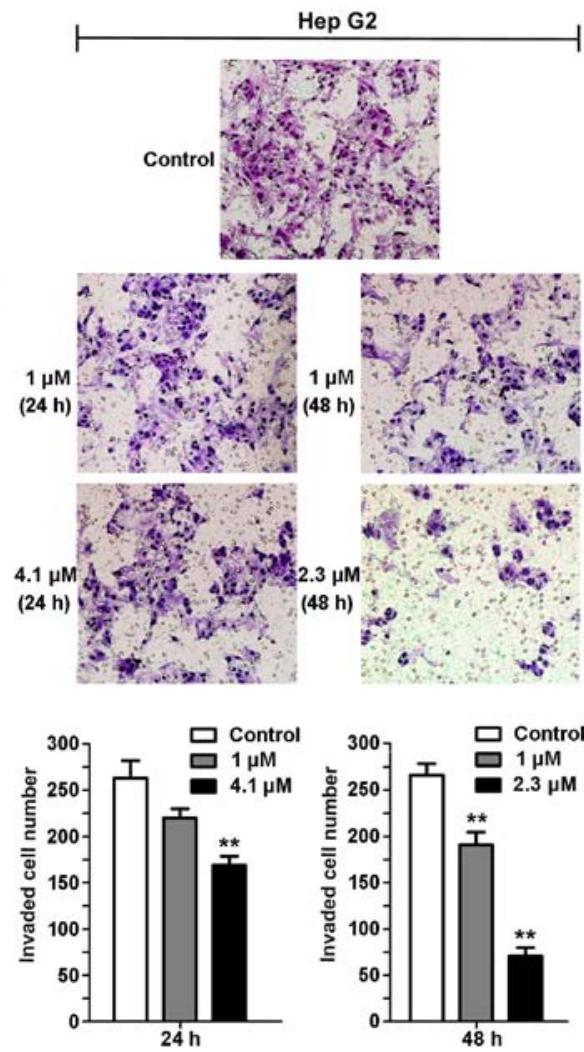

Figure 6. Effects of fordin on the invasiveness of U-2 OS and HepG2 cells. (A) Treatment of cells with fordin for 24 and 48 h significantly inhibited invasive behavior. Magnification, $\mathrm{x} 10$. (B) Number of transmembrane cells following fordin treatment. ${ }^{*} \mathrm{P}<0.05$ and ${ }^{* *} \mathrm{P}<0.001$ vs. untreated control group. 
Table II. Identification of the expressed protein by mass spectrometry analysis.

\begin{tabular}{lccccl}
\hline $\begin{array}{l}\text { Identified } \\
\text { protein }\end{array}$ & $\begin{array}{c}\text { NCBI } \\
\text { accession }\end{array}$ & $\begin{array}{c}\text { MW } \\
(\mathrm{kDa})\end{array}$ & $\begin{array}{c}\text { Coverage } \\
(\%)\end{array}$ & $\begin{array}{c}\text { Score } \\
\text { sequest HT }\end{array}$ & \multicolumn{1}{c}{ Matched peptides } \\
\hline$v f$-RIP & MF521485 & 28.3 & 54 & 518.05 & $\begin{array}{l}\text { LQTQLGVLALSDGIYTLNK; LSSGIQTADANGK; } \\
\text { SGNSN GIPVLSATVAEAK; VITNFG QR; ATTYLFKGTK; }\end{array}$ \\
& & & & & $\begin{array}{l}\text { FKPLP DVTSRENNWGK; KGADRL QTQLGVLALSDGIYTLNK; } \\
\text { FSGSYDDLKKK; GADRLQ TQLGVLALSDGIYTLNK; } \\
\end{array}$ \\
& & & & & \\
& & & & & \\
\hline
\end{tabular}

$v f$-RIP, Vernicia fordii ribosome inactivating protein.

A

A
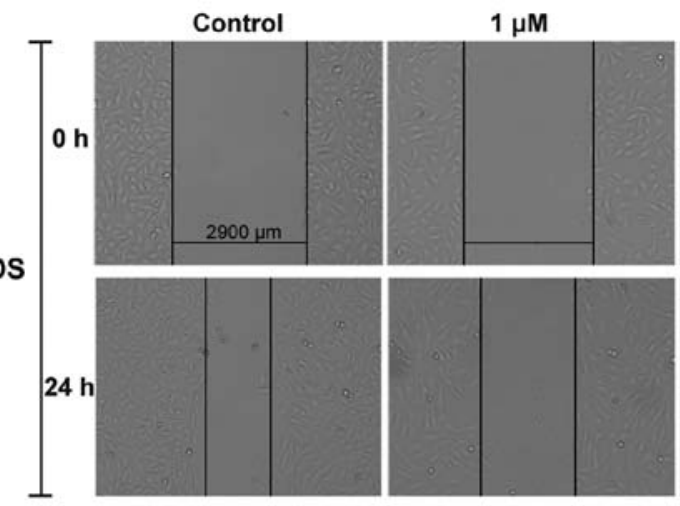

$\mathrm{U}-2$ os
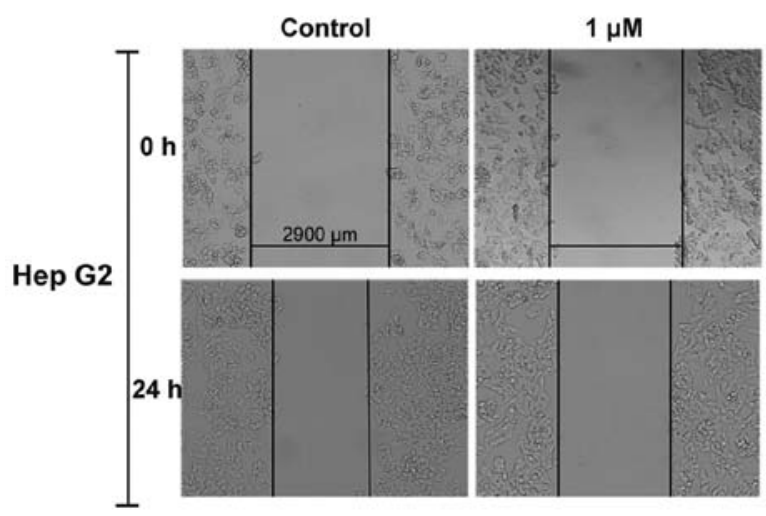

$3.6 \mu \mathrm{M}$
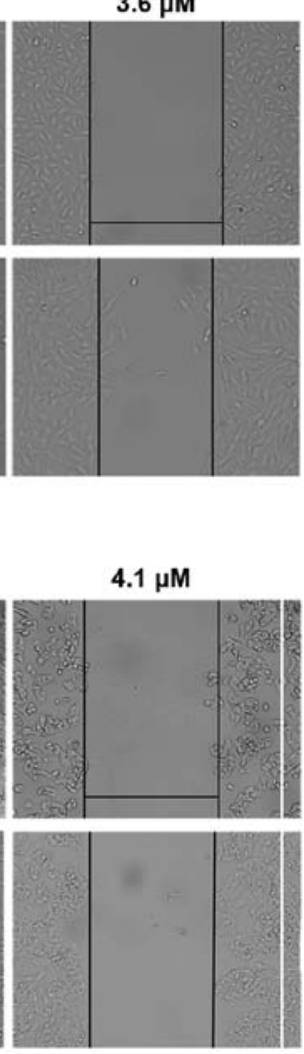

B
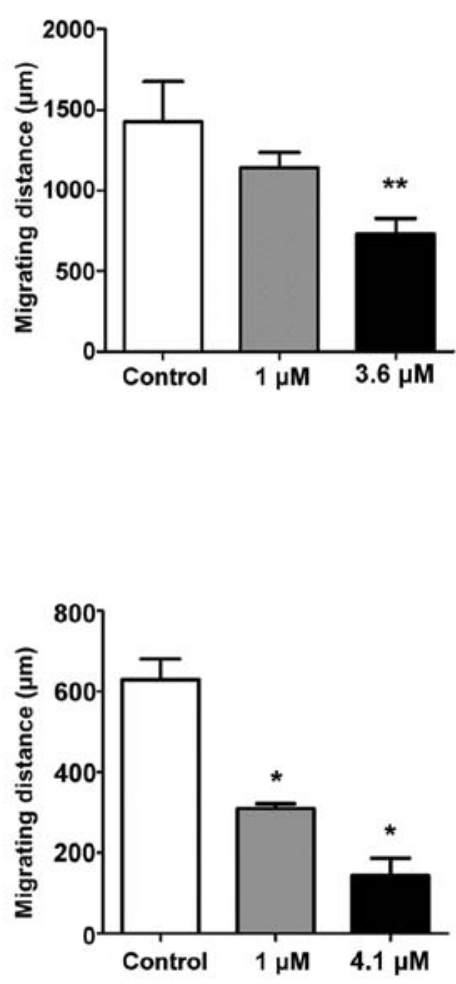

Figure 7. Effects of fordin on scratch-healing response. Treatment of (A) U-2 OS and HepG2 cells with fordin reduced the ability to cover the scratched area in culture plates. (B) Migrating distance of U-2 OS and HepG2 cells following fordin treatment. ${ }^{*} \mathrm{P}<0.05$ and ${ }^{* *} \mathrm{P}<0.001$ vs. untreated control group.

with fordin $\left(1 \mu \mathrm{M}\right.$ and $\left.\mathrm{IC}_{20}\right)$, respectively. The reduction was more pronounced for the cells treated with fordin $(1 \mu \mathrm{M}$ and $\mathrm{IC}_{20}$ ) for $48 \mathrm{~h}$ (74 and 92\%, respectively; $\mathrm{P}<0.001$ ). The number of HepG2 cells was decreased only by $16 \%(\mathrm{P}=0.0548)$ and $35 \%(\mathrm{P}<0.001)$ following 24 and $48 \mathrm{~h}$ treatment with fordin $(1 \mu \mathrm{M})$, respectively. Following 24 and $48 \mathrm{~h}$ treatment with fordin $\left(\mathrm{IC}_{20}\right)$, the reduction in invasive cell number increased to $28 \%(\mathrm{P}<0.001)$ and $73 \%(\mathrm{P}<0.001)$, respectively.

A scratch assay was used to monitor the ability of U-2 OS and HepG2 cells to cover the vacant scuffed area introduced by scratching for $24 \mathrm{~h}$. As shown in Fig. 7, the ability of cells treated with fordin to cover the scratched area was reduced. No apparent morphologic signs of treatment-related toxicity were shown at a low concentration of fordin $\left(1 \mu \mathrm{M}\right.$ and $\left.\mathrm{IC}_{20}\right)$.

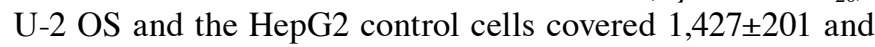

$629 \pm 36 \mu \mathrm{m}$ distances between the scratched edges following a 24-h incubation period, respectively. Fordin $(1 \mu \mathrm{M})$ exposure inhibited the migration potential by $20 \%(1,143 \pm 77 \mu \mathrm{m})$ and $51 \%(310 \pm 51 \mu \mathrm{m})$ in the U-2 OS and HepG2 cells, respectively. The effects were more marked at a higher concentration of fordin $\left(\mathrm{IC}_{20}\right)$, with a $49 \%(730 \pm 79 \mu \mathrm{m})$ and $77 \%(143 \pm 43 \mu \mathrm{m})$ decrease of the migration potential of U-2 OS and HepG2 cells, respectively.

RT-qPCR and western blot analysis were used to examine the effects of fordin on several invasion-relevant genes (Fig. 8). Following fordin exposure of the U-2 OS cells (Fig. 8A, C and D), the maximum inhibition of the mRNA and protein levels of the MMP-9 gene with migratory potential was 35 - and 4.8-fold $(\mathrm{P}<0.001)$, respectively. A maximum induction of 3.5-fold for the mRNA level of tissue inhibitor of 
Table III. ICs of fordin in the selected cell lines.

\begin{tabular}{|c|c|c|c|c|c|c|c|c|c|}
\hline \multirow[b]{2}{*}{ Cell line } & \multicolumn{3}{|c|}{$\mathrm{IC}_{20}(\mu \mathrm{M})$} & \multicolumn{3}{|c|}{$\mathrm{IC}_{50}(\mu \mathrm{M})$} & \multicolumn{3}{|c|}{$\mathrm{IC}_{70}(\mu \mathrm{M})$} \\
\hline & $24 \mathrm{~h}$ & $48 \mathrm{~h}$ & $72 \mathrm{~h}$ & $24 \mathrm{~h}$ & $48 \mathrm{~h}$ & $72 \mathrm{~h}$ & $24 \mathrm{~h}$ & $48 \mathrm{~h}$ & $72 \mathrm{~h}$ \\
\hline U-2 OS & 3.66 & 2.22 & 0.18 & 6.85 & 5.43 & 2.22 & 9.25 & 6.75 & 6.12 \\
\hline Hep G2 & 4.19 & 2.38 & 1.48 & 7.48 & 6.28 & 5.88 & 9.94 & 8.72 & 7.58 \\
\hline HeLa & 7.64 & 5.05 & & 12.97 & 10.25 & & 14.12 & 13.22 & \\
\hline A549 & 8.61 & 6.38 & & 15.55 & 10.50 & & 15.26 & 13.21 & \\
\hline MRC-5 & $>200$ & 28.91 & & $>400$ & 34.64 & & $>400$ & 38.02 & \\
\hline
\end{tabular}

IC, inhibitory concentration.

A

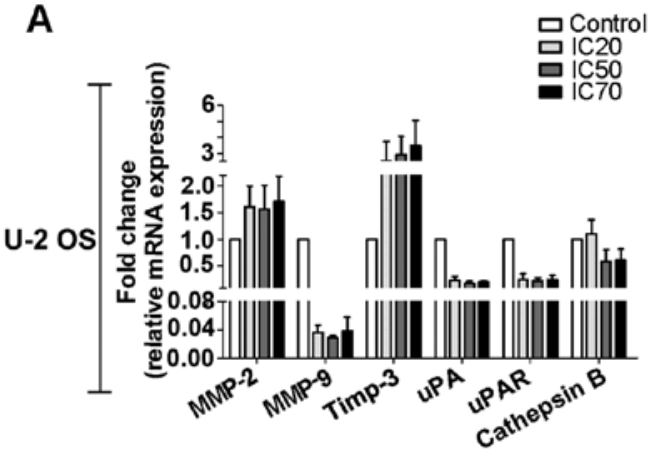

C

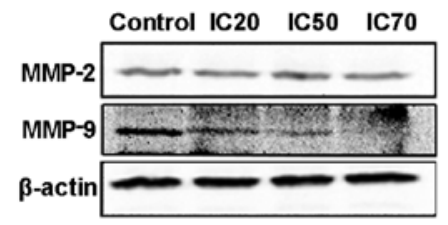

E

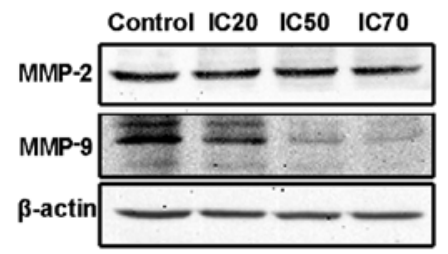

B

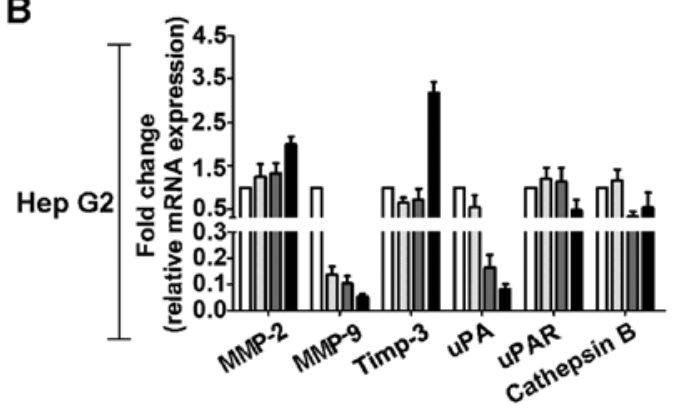

D

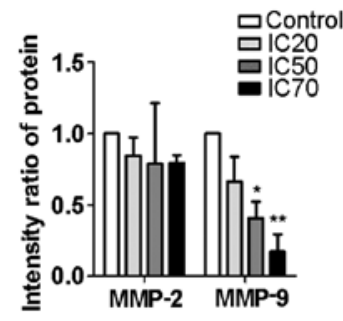

$\mathbf{F}$

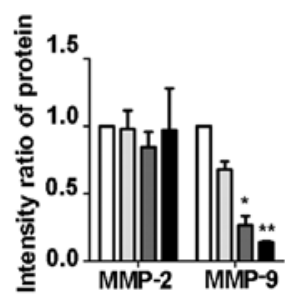

Figure 8. Effects of fordin on the expression of metastasis-related genes in U-2 OS and HepG2 cells. Cells were treated with fordin $\left(\mathrm{IC}_{20}, \mathrm{IC}_{50}\right.$ or IC $\left.\mathrm{IC}_{70}\right)$ for $24 \mathrm{~h}$. mRNA levels of invasion relevant genes were analyzed in (A) U-2 OS and (B) HepG2 cells by reverse transcription-quantitative polymerase chain reaction analysis. Protein expression of levels MMP-2 and MMP-9 were analyzed by western blot analysis and normalized to the level of $\beta$-actin. (C) Blot and (D) quantification in U-2 OS cells; (E) blot and (F) quantification in HepG2 cells. "P<0.05 and ${ }^{* *} \mathrm{P}<0.001$ vs. untreated control group. MMP, matrix metalloproteinase; Timp3, tissue inhibitor of metalloproteinase 3; IC, inhibitory concentration.

metalloproteinase (Timp)-3, an inhibitor of the MMP family, was also observed. In the HepG2 cells (Fig. 8B, E and F), the mRNA and protein levels of MMP-9 were decreased in a dose-dependent manner with a maximum reduction of 19- and 6.2-fold $(\mathrm{P}<0.001)$, respectively. The mRNA level of Timp-3 was not affected by fordin treatment. The mRNA and protein levels of MMP-2 gene did not differ significantly between control and treated groups in either cell line. In addition, in the two cell lines, fordin had inhibitory effects on the mRNA levels of cathepsin B (maximum, 1.0- and 2.0-fold), urokinase plasminogen activator (uPA; maximum, 5.1- and 11.7-fold), and uPA receptor (maximum, 3.8- and 1.6-fold) (Fig. 8A and B), which have significant roles in tumor invasion. Downregulation of the aforementioned metastasis-related genes may be important in the suppression of U-2 OS and HepG2 cell invasion and migration caused by fordin.

Effects of fordin on the regulation of $N F-\kappa B$ signaling pathways. To investigate the effects of fordin on NF- $\kappa \mathrm{B}$ activation, the protein levels of p65 (total and phosphorylated) 
A
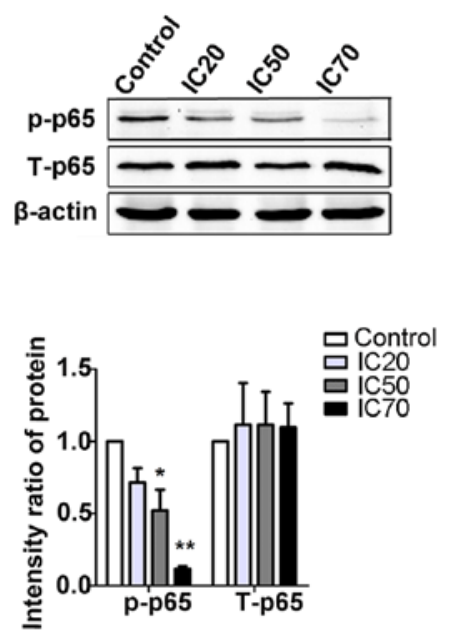

B
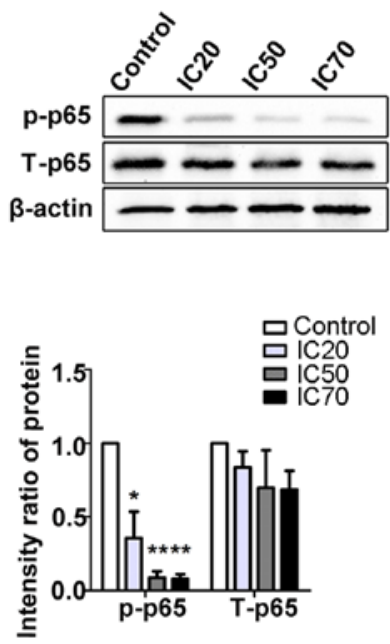

C

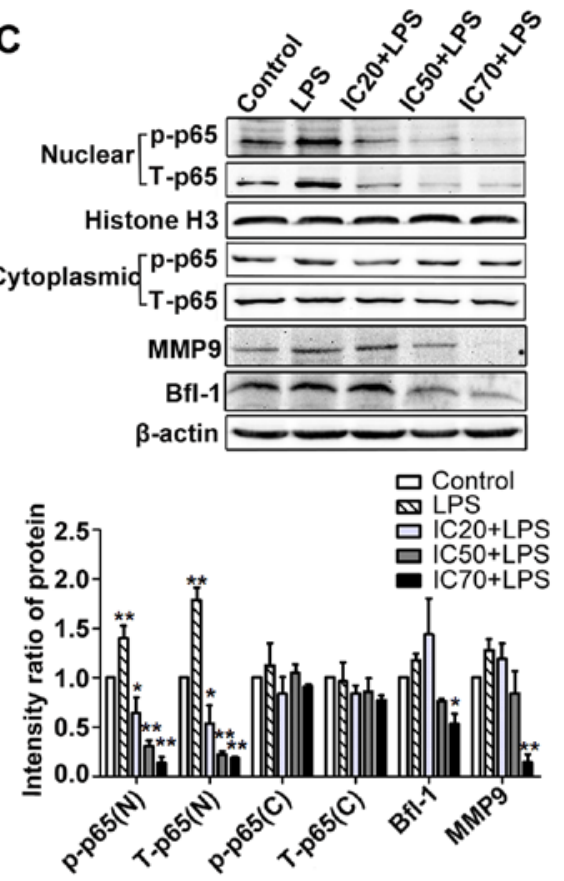

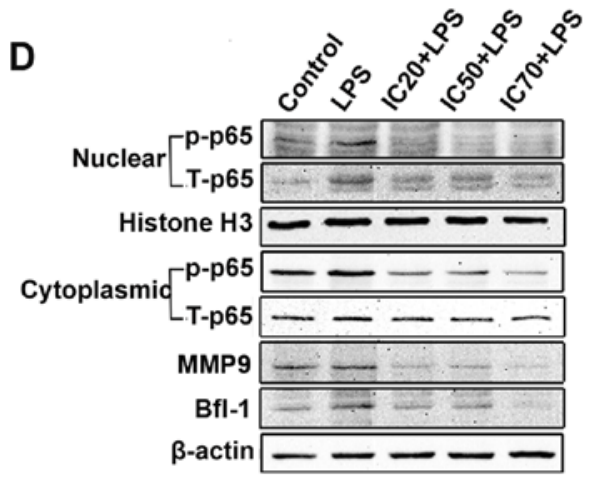

E
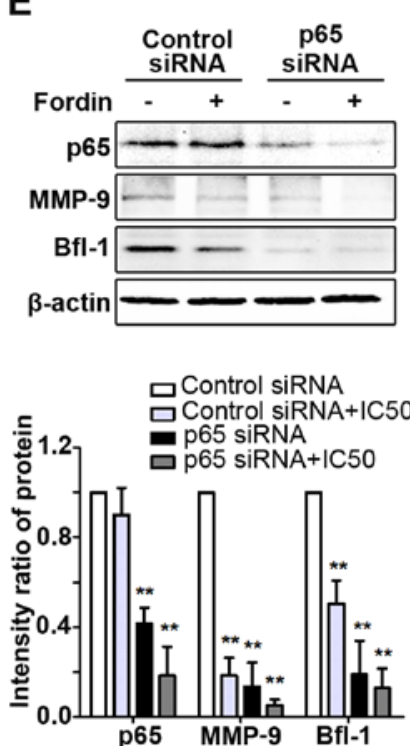

F
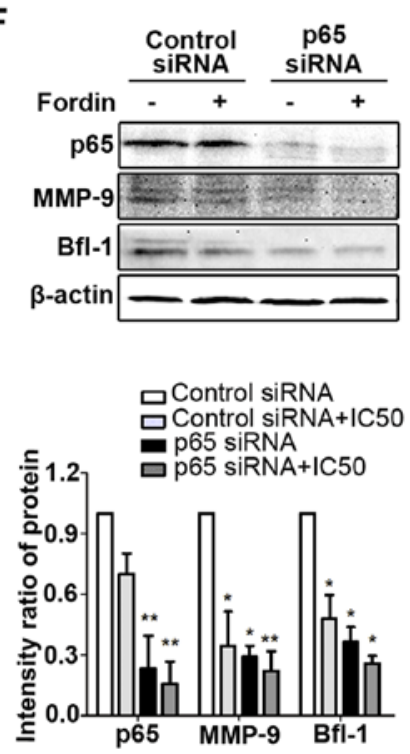

Figure 9. NF- $\mathrm{BB} / \mathrm{p} 65$ is responsible for the downregulation of MMP-9 and Bfl-1 mediated by fordin in U-2 OS and HepG2 cells. The expression of p65 (phosphorylated and total), MMP-9 and Bfl-1 were determined by western blot analysis in the various treated cells and normalized to $\beta$-actin or Histone H3. (A) U-2 OS and (B) HepG2 cells were incubated with various concentrations of fordin for $24 \mathrm{~h}$; ${ }^{*} \mathrm{P}<0.05$ and ${ }^{* *} \mathrm{P}<0.001 \mathrm{vs}$. untreated control group. (C) $\mathrm{U}-2$ OS and (D) HepG2 cells were treated with fordin and/or LPS for $24 \mathrm{~h} ;{ }^{*} \mathrm{P}<0.05$ and ${ }^{* *} \mathrm{P}<0.001$ vs. control group. (E) U-2 OS and (F) HepG2 cells transfected with p65 siRNA or control siRNA were treated with or without fordin $\left(\mathrm{IC}_{50}\right)$; ${ }^{*} \mathrm{P}<0.05$ and ${ }^{* *} \mathrm{P}<0.001$ vs. control siRNA group ( $\mathrm{n}=3$ ). siRNA, small interfering RNA; LPS, lipopolysaccharide; p-, phosphorylated; T, total; N, nuclear; C, cytoplasmic; MMP, matrix metalloproteinase; Bfl-1, B-cell lymphoma-related protein A1; IC, inhibitory concentration.

were determined in U-2 OS and HepG2 cells. As shown in Fig. 9A and B, the expression of phosphorylated p65 was significantly decreased in the treated cells; however, the total p65 expression was not changed. To further verify the effects of fordin on the inhibition of p65 activation, lipopolysaccharide $(10 \mu \mathrm{g} / \mathrm{ml})$ was used to induce NF- $\kappa \mathrm{B}$ activation. The protein levels of intra-nuclear p65 (phosphorylated and total) were markedly suppressed (maximum, 10.3- and 9.6-fold, respectively; $\mathrm{P}<0.001)$ in $\mathrm{U}-2$ OS cells treated with LPS and fordin $\left(\mathrm{IC}_{20}, \mathrm{IC}_{50}\right.$, or $\left.\mathrm{IC}_{70}\right)$ compared with the cells treated with LPS alone (Fig. 9C). Similar findings were observed in the HepG2 cells, in which the maximum reductions in intra-nuclear p65 (phosphorylated and total) expression were 8.5- and 2.6-fold ( $\mathrm{P}<0.001)$ (Fig. 9D), respectively. In the two cell lines, the protein levels of total p65 in the cytoplasm showed negligible change; however, the expression of phosphorylated p65 in the cytoplasm was downregulated in Hep G2 cells (maximum, 3.2-fold, $\mathrm{P}<0.05$ ). These results demonstrated that fordin inhibited the nuclear accumulation and phosphorylation of $\mathrm{NF}-\kappa \mathrm{B}$ in cancer cells. 
A-2 os

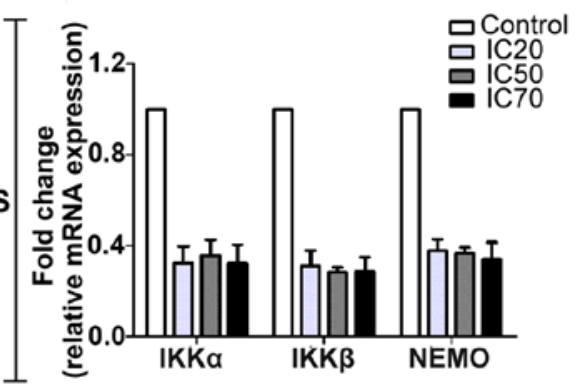

C

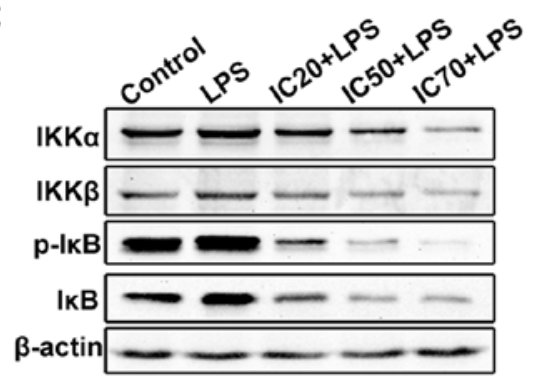

E

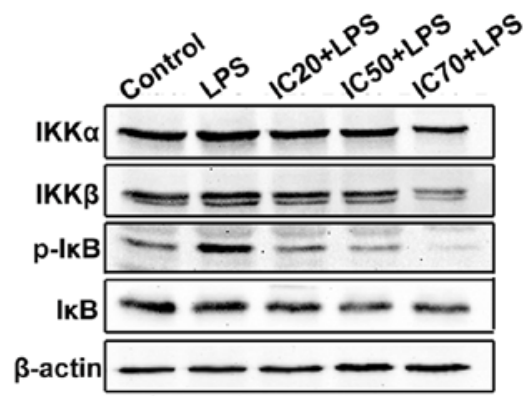

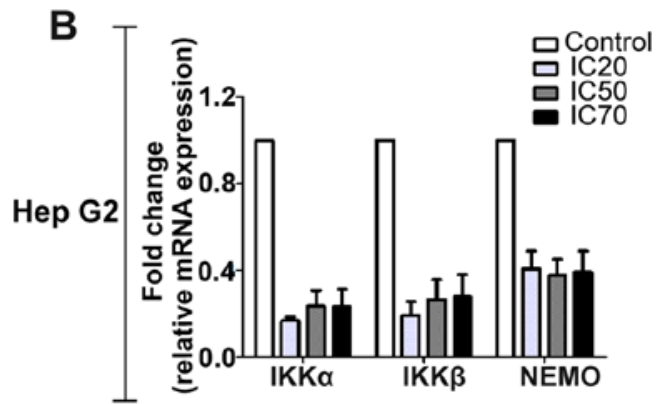

D

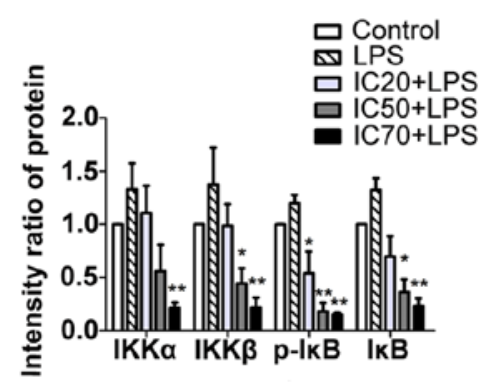

$\mathbf{F}$

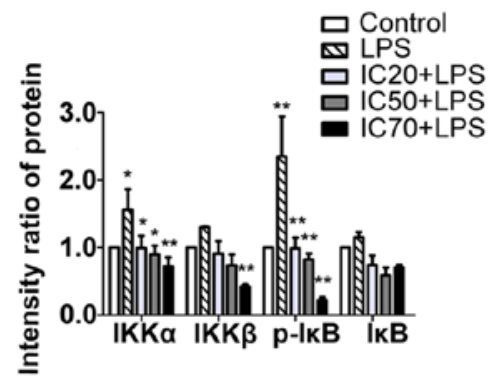

Figure 10. Expression analysis of proteins related to NF- $\mathrm{B}$ signaling pathway in U-2 OS and Hep G2 cells. mRNA expression of IKK $\alpha$, IKK $\beta$ and NEMO were analyzed in (A) U-2 OS and (B) HepG2 cells. Protein expression levels of IKK $\alpha$, IKK $\beta$ and I $\mathrm{B}$ (phosphorylated and total) were analyzed by western blot analysis. (C) Blot and (D) quantification of proteins in U-2 OS cells; (E) Blot and (F) quantification of proteins in HepG2 cells. ${ }^{*} \mathrm{P}<0.05$ and ${ }^{* *} \mathrm{P}<0.001$ vs.

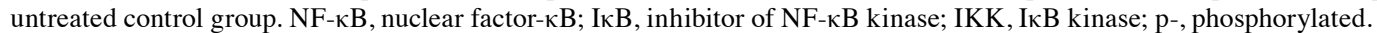

In addition, understanding whether $\mathrm{NF}-\kappa \mathrm{B}$ is involved in the regulation of the expression of Bfl-1 and MMP-9 mediated by fordin, LPS and p65 siRNA were used to regulate the activation of NF- $\kappa$ B in U-2 OS and HepG2 cells. As shown in Fig. 9C and D, upregulation of the intra-nuclear expression of p65, Bfl-1 and MMP-9 due to LPS was reduced by fordin treatment in the U-2 OS (maximum, 8.6-, 1.2- and 8.2-fold; $\mathrm{P}<0.05$ ) and HepG2 (maximum, 2.2-, 2.4- and 4.0-fold, respectively; $\mathrm{P}<0.001$ ) cells. In Fig. $9 \mathrm{E}$ and $\mathrm{F}$, the knockdown of p65 reduced the protein levels of MMP-9 and Bfl-1 in U-2 OS (6.5- and 4.3-fold, respectively; $\mathrm{P}<0.001$ vs. control siRNA transfected cells) and HepG2 cells (2.4- and 1.7-fold, respectively; $\mathrm{P}<0.05$ vs. control siRNA transfected cells). The effects of fordin on the expression of MMP-9 and Bfl-1 were weaker in the p65 siRNA-transfected cells (U-2 OS: 1.7- and 0.5-fold; HepG2: 0.3- and 0.4-fold, respectively; P>0.05) than in control siRNA-transfected cells (U-2 OS: 4.5- and 1.0-fold; Hep G2: 1.9- and 1.1-fold, respectively; $\mathrm{P}<0.05)$. These findings revealed that $\mathrm{NF}-\kappa \mathrm{B}$ regulated the expression of Bfl-1 and MMP-9 in U-2 OS and HepG2 cells, and fordin downregulated the expression of Bfl-1 and MMP-9, at least in part, associated with the inactivation of $N F-\kappa B$.
The finding that fordin inhibited the nuclear accumulation and phosphorylation of NF- $\kappa \mathrm{B}$ in cancer cells was verified by a corollary study (Fig. 10A-F). Fordin treatment decreased the mRNA levels of IKK $\alpha$ (maximum, 2.2- and 5.0-fold) and IKK $\beta$ (maximum, 2.6- and 4.7-fold) in the U-2 OS and HepG2 cells, respectively. The protein levels of IKK $\alpha$ and IKK $\beta$ were decreased by a maximum of 4.5 - and 4.3 -fold $(\mathrm{P}<0.001)$ in $\mathrm{U}-2$ OS cells, respectively. The maximum reduction in IKK $\alpha$ and IKK $\beta$ was 0.9 - and 2.1-fold $(\mathrm{P}<0.001)$ in the HepG2 cells, respectively. The protein levels of phosphorylated $\mathrm{I} \kappa \mathrm{B}$ were also reduced in U-2 OS and HepG2 cells (maximum, 6.6- and 11.6-fold, respectively; $\mathrm{P}<0.001)$.

\section{Discussion}

$V$. fordii, belonging to Euphorbiaceae, is a woody oil plant and prevalent in southern China. The seeds of $V$. fordii are well-known for their potential as a raw material to produce biodiesel $(16,33)$. The roots and leaves of $V$. fordii have been widely used in folk medicine. Based on our previous transcriptome analysis, information on a novel RIP (fordin) gene from $V$. fordii was retrieved. Fordin is a 279 -amino-acid 


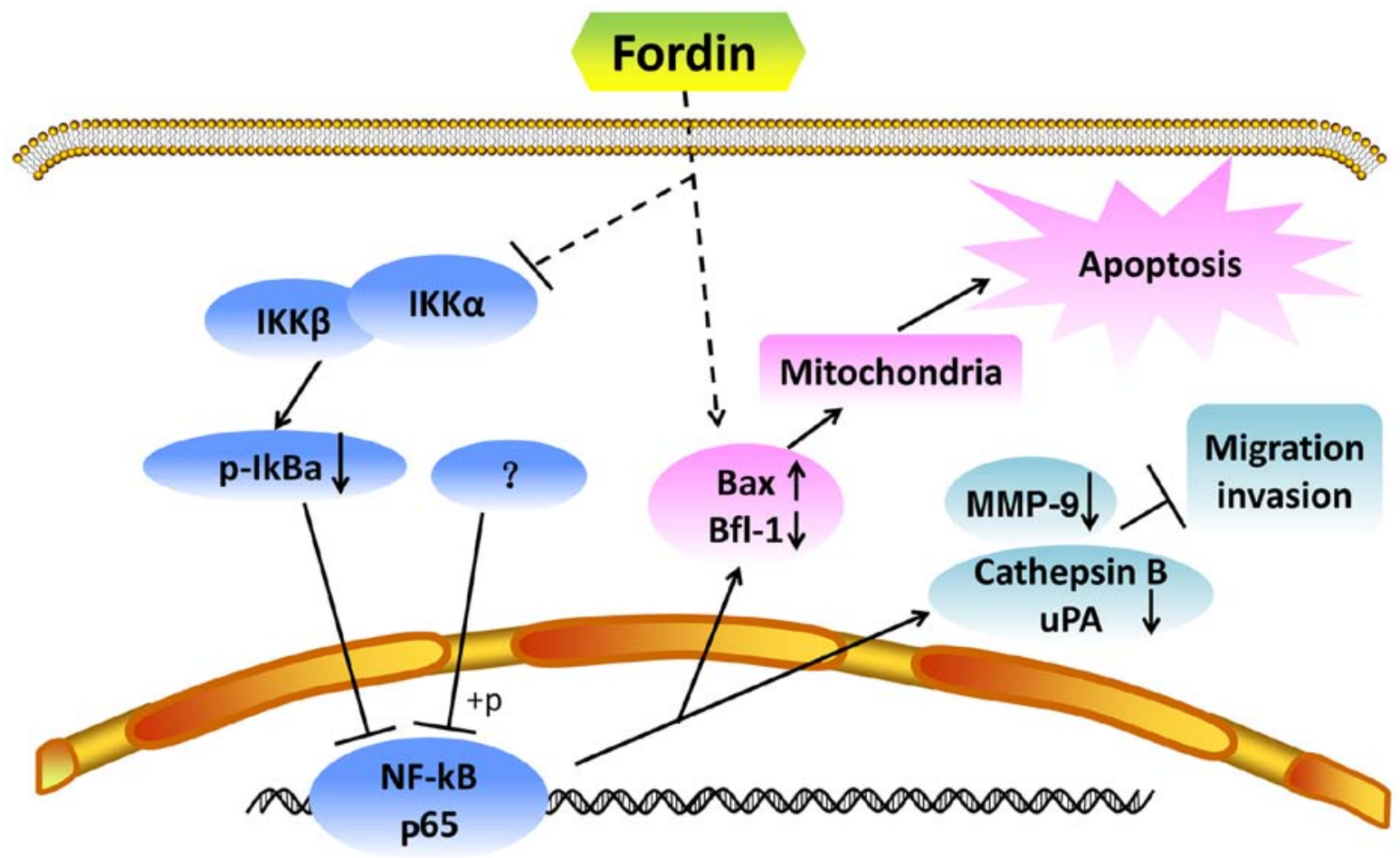

Figure 11. Schematic overview of the fordin-mediated signaling pathway. Based on the published literature and findings from the previous study, a fordin-

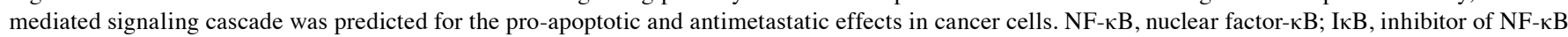
kinase; IKK, IкB kinase; p-, phosphorylated; Bax, B-cell lymphoma-2-associated X protein; Bfl-1, B-cell lymphoma-2-related protein A1; MMP, matrix metalloproteinase.

polypeptide with a molecular weight of $30.781 \mathrm{kDa}$. The alignment results with other RIP sequences have demonstrated that fordin is closely associated with type I RIPs with respect to the conserved region, which is also the ribosome-inactivating region. In the present study, the open reading frame of the fordin gene was successfully obtained from $V$. fordii leaves. In consideration of the difficulty in purifying this protein from the plant, a novel method was established to obtain soluble and active fordin from the E. coli expression system. This technique allows mass quantities of fordin to be obtained for further biological activity investigations and application. The results of the enzyme activity assay showed that fordin had $\mathrm{N}$-glycosidase activity which may lead to ribosome inactivation, as with the majority of the reported RIPs from different plant species (32).

To determine the potential of fordin in cancer therapy, the present study examined its specific action on the viability of tumor and normal cells. Considering the $\mathrm{IC}_{50}$ values in the viability assay, fordin exhibited more toxicity towards four tumor cell lines than the normal cell line. This finding may be due to fordin being a type I RIP without a B-chain to bind the cell surface glycoconjugate to increase the internalization of activity A-chain into normal cells. Compared with fordin, ricin exhibits marked toxicity towards normal cells, as the LD50 of mice can be as low as $1-10 \mu \mathrm{g} / \mathrm{kg}$ (34). The inhibitory effect of fordin on four tumor cell lines was exerted in a time- and dosedependent manner. The U-2 OS and HepG2 cell lines were more susceptible to the fordin cytotoxicity. It is reported that type I RIPs show diverse toxic effects against different tumor cells due to the differential expression of receptors for binding, the presence of sialyl caps, and specific molecular routes developed by cancer cells over time $(35,36)$. The mechanism of the internalization of fordin requires further investigation. Furthermore, in U-2 OS and HepG2 cells, a sharp decline in survival rates was observed following fordin $(>1 \mu \mathrm{M})$ exposure. However, the effects were not in proportion to further increases in fordin concentrations $(>7.5 \mu \mathrm{M})$. This observation indicates the presence of possible feedback mechanisms and successful resistance to high fordin concentrations in cancer cells.

Fordin also led to the inhibition of invasion and migration of U-2 OS and HepG2 cells, as observed by scratch and Transwell assays. The migratory and invasive abilities of cancer cells from the primary site to distant organs are essential for metastasis. At the molecular level, fordin exposure suppressed the mRNA levels of uPA, uPAR, and cathepsin B, which are considered to be crucial in the invasion of tumor cells by degradation of the extracellular matrix (ECM) (37). Reports have also claimed that cathepsin-dependent and uPA-mediated tumor invasion are achieved by inducing the expression of MMP-2 and MMP-9 (22). Overexpression of the MMP family genes has been reported to be correlated with cancer metastasis (38-41). Therefore, the present study evaluated the effects of fordin on the expression of MMP-2 and MMP-9. The results revealed that fordin exposure downregulated the mRNA and protein levels of MMP-9, which demonstrated the importance in tumorigenesis and metastasis within the MMP family (42). Therefore, the observed anti-metastatic effects of fordin in cancer cells are associated with the downregulation of metastasis-dependent gene (MMP-9) expression.

To clarify the reasoning behind the fordin-mediated anti-proliferative and cytotoxic effects, the present study 
investigated the possible effects on the induction of apoptosis in cancer (U-2 OS and HepG2) cells and normal (MRC-5) cells. Fordin induced more considerable signs of apoptosis in the two cancer cells than in the normal cells. These apoptotic effects were further confirmed by nuclear staining, which showed chromatin condensation and nuclear fragmentation, and the Annexin V-FITC assay with an increased percentage of Annexin V-FITC-positive cells. Searching for the molecular logic of these apoptotic effects, it was found that fordin exposure led to the induction of pro-apoptotic (Bax) genes, as shown by RT-qPCR and western blot analyses. Several studies have indicated the suppression of anti-apoptotic (Bcl-2 and Bcl-xL) gene expression following RIP treatment $(18,21,43)$. However, in the present study, fordin had no significant effect on the levels of $\mathrm{Bcl}-2$ and $\mathrm{Bcl}-\mathrm{xL}$. The expression ratio of $\mathrm{Bax} / \mathrm{Bcl}-2$ was increased in a concentration-dependent manner. The mRNA and protein levels of Bfl-1 were also markedly downregulated following fordin exposure. Bfl-1, known as A1, is a Bcl-2 homolog and a direct target of $\mathrm{NF}-\kappa \mathrm{B}(44,45)$. It is required to prevent apoptosis in various cells (46). However, there are few reports on its role in the apoptosis induced by RIPs. In the present study, the alterations in the expression of Bfl-1 and Bax were crucial in the apoptosis induced by fordin in U-2 OS and HepG2 cells.

Following fordin treatment, suppression of the nuclear accumulation of NF- $\kappa \mathrm{B}$ was observed, which resulted from a decrease in the phosphorylation level of I $\mathrm{B}$ caused by quelling the expression of IKK $\alpha$ and IKK $\beta$. Suppression of the nuclear accumulation and phosphorylation of $N F-\kappa B$ by fordin treatment effectively inhibited the activation of $N F-\kappa B$ in the cells. A number of studies have shown the pivotal position of $\mathrm{NF}-\kappa \mathrm{B}$ in tumor initiation, progression, and invasion in various types of human cancer (47-50). Several RIPs, including TCS, Viscum album agglutinin and Abrus agglutinin, have been shown to induce apoptosis through quelling activation of the $\mathrm{NF}-\kappa \mathrm{B}$ signaling pathway (51-54). In consideration of these findings, the ability of fordin to suppress $N F-\kappa B$ in cancer cells is of paramount importance. Furthermore, it is widely reported that the overexpression of MMP and Bcl-2 family are closely associated with the activation of NF- $\kappa \mathrm{B}(22,55)$. The present focused on the effects of fordin on the expression of MMP-9 and Bfl-1 in cells treated with LPS, which is known to activate the NF- $\mathrm{B}$ pathway. The results revealed that the expression of intranuclear p65 (phosphorylated and total), Bfl-1 and MMP-9 were increased in the LPS-treated cells, but decreased following fordin treatment. In addition, the protein levels of MMP-9 and Bfl-1 were decreased in the cells with siRNA-induced p65 knockdown. The effects of fordin on the expression of MMP-9 and Bfl-1 were partly inhibited in the p65 siRNA-transfected cells. These findings suggested that $\mathrm{NF}-\kappa \mathrm{B}$ is responsible for the downregulated expression of MMP-9 and Bfl-1 mediated by fordin. This suggests that an $\mathrm{NF}-\kappa \mathrm{B}-$ mediated pathway is involved in the inhibition of invasion and induction of apoptosis by fordin exposure in U-2 OS and HepG2 cells (Fig. 11).

In conclusion, the present study revealed for the first time, to the best of our knowledge, the presence of fordin and the antitumor activity of fordin in vitro. The results demonstrated that fordin induced multi-faceted antineoplastic effects in U-2 OS and HepG2 cells, including antiproliferation and anti-invasion effects, and the induction of apoptosis. It appears that $\mathrm{NF}-\kappa \mathrm{B}$ is one of the main driving factors for fordin-mediated responses. The results suggested that fordin inhibited the invasion of cancer cells, possibly via suppression of the NF- $\mathrm{BB}$-dependent activation of MMPs, and induced apoptosis partly through $\mathrm{NF}-\kappa \mathrm{B}$-mediated pro-apoptotic mechanisms. Taken together, the diverse anticancer effects of fordin suggest its therapeutic potential on restricting tumor growth and reducing the risks of cancer metastasis as a naturally therapeutic agent. However, fordin also may possess adverse effects, including severe systemic anaphylaxis, immunogenicity and toxicity, as with other reported RIPs. Further investigations of fordin, in terms of its antitumor activity in vivo, the precise mechanisms underlying its effects, and targeted toxins, are warranted.

\section{Acknowledgements}

The authors wish to acknowledge Professor Fanfor for his provision of the pET28b-SUMO and p28ULP expression vector.

\section{Funding}

This study was funded by the National Natural Science Foundation of China (grant nos. 11375232 and 31500531), the Science and Technology Service program of Chinese Academy of Sciences (grant nos. KFJ-STS-ZDTP-002 and KFJ-SW-STS-143-4), the Grant of the President Foundation of Hefei Institutes of Physical Science of Chinese Academy of Sciences (grant nos. YZJJ201502 and YZJJ201619), the major special project of Anhui Province (grant no. 16030701103), and the Innovative Program of Development Foundation of Hefei Center for Physical Science and Technology (grant no. 2016FXCX005).

\section{Availability of data and materials}

The datasets used and/or analyzed during the current study are available from the corresponding author on reasonable request.

\section{Authors' contributions}

LW, JW and WL conceived and designed the research; WL, YM, XC and JN carried out gene cloning and protein expression assays; WL, RZ and YW performed the in vitro cell experiments; WL and JW analyzed the data. All authors reviewed the manuscript. All authors have read and approved the final manuscript.

\section{Ethics approval and consent to participate}

Not applicable.

\section{Patient consent for publication}

Not applicable.

\section{Competing interests}

The authors declare that they have no competing interests. 


\section{References}

1. Girbés T, Ferreras JM, Arias FJ and Stirpe F: Description, distribution, activity and phylogenetic relationship of ribosomeinactivating proteins in plants, fungi and bacteria. Mini Rev Med Chem 4: 461-476, 2004.

2. Stirpe F: Ribosome-inactivating proteins. Toxicon 44: 371-383, 2004.

3. Stirpe F and Battelli MG: Ribosome-inactivating proteins: Progress and problems. Cell Mol Life Sci 63: 1850-1866, 2006.

4. Li J, Xia X, Ke Y, Nie H, Smith MA and Zhu X: Trichosanthin induced apoptosis in HL-60 cells via mitochondrial and endoplasmic reticulum stress signaling pathways. Biochim Biophys Acta 1770: 1169-1180, 2007.

5. Polito L, Bortolotti M, Mercatelli D, Battelli MG and Bolognesi A Saporin-S6: A useful tool in cancer therapy. Toxins (Basel) 5 : 1698-1722, 2013.

6. Mohamed MS, Veeranarayanan S, Poulose AC, Nagaoka Y, Minegishi H, Yoshida Y, Maekawa T and Kumar DS: Type 1 ribotoxin-curcin conjugated biogenic gold nanoparticles for a multimodal therapeutic approach towards brain cancer. Biochim Biophys Acta 1840: 1657-1669, 2014.

7. Smith ME and Hayoun MA: Toxicity, Ricin. StatPearls (Internet): Jun 10, 2017 (Epub ahead of print).

8. Puri M, Kaur I, Perugini MA and Gupta RC: Ribosomeinactivating proteins: Current status and biomedical applications Drug Discov Today 17: 774-783, 2012.

9. Puri M: 'Momordica balsamina: a medicinal and neutraceutical plant for health care management'. Comments: biotechnological potential of M. balsamina revealed. Curr Pharm Biotechnol 11: 229-229, 2010.

10. Polito L, Bortolotti M, Pedrazzi M, Mercatelli D, Battelli MG and Bolognesi A: Apoptosis and necroptosis induced by stenodactylin in neuroblastoma cells can be completely prevented through caspase inhibition plus catalase or necrostatin-1. Phytomedicine 23 . 32-41, 2016

11. Panda PK, Behera B, Meher BR, Das DN, Mukhopadhyay S, Sinha N, Naik PP, Roy B, Das J, Paul S, et al: Abrus Agglutinin, a type II ribosome inactivating protein inhibits $\mathrm{Akt} / \mathrm{PH}$ domain to induce endoplasmic reticulum stress mediated autophagydependent cell death. Mol Carcinog 56: 389-401, 2017.

12. College JN: Dictionary of Chinese Materia Medica. Journal, 1977.

13. Piccirilli A, Piccardi N and Miska P: Use of at least one conjugated triene-containing fatty acid for preparing a medicine for treating inflammation. US Patent 2008/0045594 A1. Filed July 26, 2004; issued February 2, 2008.

14. Igarashi $\mathrm{M}$ and Miyazawa T: Newly recognized cytotoxic effect of conjugated trienoic fatty acids on cultured human tumor cells Cancer Lett 148: 173-179, 2000.

15. Belury MA: Dietary conjugated linoleic acid in health: Physiological effects and mechanisms of action. Annu Rev Nutr 22: 505-531, 2002.

16. Mao Y, Liu W, Chen X, Xu Y, Lu W, Hou J, Ni J, Wang Y and Wu L: Flower development and sex determination between male and female flowers in Vernicia fordii. Front Plant Sci 8: 1291, 2017.

17. Polito L, Bortolotti M, Maiello S, Battelli MG and Bolognesi A: Plants producing ribosome-inactivating proteins in traditional medicine. Molecules 21: 21, 2016

18. Fang EF, Zhang CZ, Wong JH, Shen JY, Li CH and Ng TB: The MAP30 protein from bitter gourd (Momordica charantia) seeds promotes apoptosis in liver cancer cells in vitro and in vivo. Cancer Lett 324: 66-74, 2012.

19. Pan WL, Wong JH, Fang EF, Chan YS, Ng TB and Cheung RC: Preferential cytotoxicity of the type I ribosome inactivating protein alpha-momorcharin on human nasopharyngeal carcinoma cells under normoxia and hypoxia. Biochem Pharmacol 89: 329-339, 2014

20. Roy S, Axup JY, Forsyth JS, Goswami RK, Hutchins BM, Bajuri KM, Kazane SA, Smider VV, Felding BH and Sinha SC: SMI-Ribosome inactivating protein conjugates selectively inhibit tumor cell growth. Chem Commun (Camb) 53: 4234-4237, 2017

21. Wang $\mathrm{P}, \mathrm{Xu} \mathrm{J}$ and Zhang C: CREB, a possible upstream regulator of Bcl-2 in trichosanthin-induced HeLa cell apoptosis. Mol Biol Rep 37: 1891-1896, 2010.

22. Baud V and Karin M: Is NF-kappaB a good target for cancer therapy? Hopes and pitfalls. Nat Rev Drug Discov 8: 33-40, 2009.
23. Sweeney CJ, Mehrotra S, Sadaria MR, Kumar S, Shortle NH, Roman Y, Sheridan C, Campbell RA, Murry DJ, Badve S, et al: The sesquiterpene lactone parthenolide in combination with docetaxel reduces metastasis and improves survival in a xenograft model of breast cancer. Mol Cancer Ther 4: 1004-1012, 2005.

24. Lwin T, Hazlehurst LA, Li Z, Dessureault S, Sotomayor E, Moscinski LC, Dalton WS and Tao J: Bone marrow stromal cells prevent apoptosis of lymphoma cells by upregulation of anti-apoptotic proteins associated with activation of NF-kappaB (RelB/p52) in non-Hodgkin's lymphoma cells. Leukemia 21: 1521-1531, 2007.

25. Cao JP, Niu HY, Wang HJ, Huang XG and Gao DS: NF- $\kappa B$ $\mathrm{p} 65 / \mathrm{p} 52$ plays a role in GDNF up-regulating Bcl-2 and Bcl-w expression in 6-OHDA-induced apoptosis of MN9D cell. Int J Neurosci 123: 705-710, 2013

26. Hecht M, von Metzler I, Sack K, Kaiser M and Sezer O: Interactions of myeloma cells with osteoclasts promote tumour expansion and bone degradation through activation of a complex signalling network and upregulation of cathepsin $\mathrm{K}$, matrix metalloproteinases (MMPs) and urokinase plasminogen activator (uPA). Exp Cell Res 314: 1082-1093, 2008.

27. Feng AH, Zhang GM, Qi ZG and Fan J: Functional determination of recombinant maize $f$ and $m$ type rhioredoxin and entrapment of target proteins. Zhongguo Sheng Wu Gong Cheng Za Zhi 30: 63-68, 2010 (In Chinese)

28. Malakhov MP, Mattern MR, Malakhova OA, Drinker M, Weeks SD and Butt TR: SUMO fusions and SUMO-specific protease for efficient expression and purification of proteins. J Struct Funct Genomics 5: 75-86, 2004 .

29. Wu Y, Mao Y, Jin S, Hou J, Du H, Yang M and Wu L: Identification, characterization and structure analysis of a type I ribosomeinactivating protein from Sapium sebiferum (Euphorbiaceae). Biochem Biophys Res Commun 463: 557-562, 2015.

30. López-Terrada D, Cheung SW, Finegold MJ and Knowles BB Hep G2 is a hepatoblastoma-derived cell line. Hum Pathol 40: $1512-1515,2009$.

31. Livak KJ and Schmittgen TD: Analysis of relative gene expression data using real-time quantitative PCR and the 2(- $\Delta \Delta \mathrm{C}(\mathrm{T}))$ method. Methods 25: 402-408, 2001

32. Severino V, Paiardini A, Pascarella S, Parente A and Chambery A: Structural analysis of toxic volkensin, a type 2 ribosome inactivating protein from Adenia volkensii Harm (kilyambiti plant): Molecular modeling and surface analysis by computational methods and limited proteolysis. Int J Biol Macromol 45: 407-413, 2009.

33. Chang $\mathrm{CH}$, Lin $\mathrm{HC}$, Chang $\mathrm{CH}$, Chang $\mathrm{CC}$ and $\mathrm{Hsu} \mathrm{SH}$ : Potential of domestically produced and imported tung (Vernicia fordii) seeds for biofuels. J Biobased Mater Bioenergy 7: 512-515, 2013.

34. Schep LJ, Temple WA, Butt GA and Beasley MD: Ricin as a weapon of mass terror - separating fact from fiction. Environ Int 35: 1267-1271, 2009.

35. Bayer H, Essig K, Stanzel S, Frank M, Gildersleeve JC, Berger MR and Voss C: Evaluation of riproximin binding properties reveals a novel mechanism for cellular targeting. J Biol Chem 287: 35873-35886, 2012.

36. Pervaiz A, Adwan $\mathrm{H}$ and Berger MR: Riproximin: A type II ribosome inactivating protein with anti-neoplastic potential induces IL24/MDA-7 and GADD genes in colorectal cancer cell lines. Int J Oncol 47: 981-990, 2015.

37. Guo M, Mathieu PA, Linebaugh B, Sloane BF and Reiners JJ Jr: Phorbol ester activation of a proteolytic cascade capable of activating latent transforming growth factor-betaL a process initiated by the exocytosis of cathepsin B. J Biol Chem 277: 14829-14837, 2002.

38. Egeblad $\mathrm{M}$ and Werb Z: New functions for the matrix metalloproteinases in cancer progression. Nat Rev Cancer 2: 161-174, 2002.

39. Ranuncolo SM, Armanasco E, Cresta C, Bal De Kier Joffe E and Puricelli L: Plasma MMP-9 (92 kDa-MMP) activity is useful in the follow-up and in the assessment of prognosis in breast cancer patients. Int J Cancer 106: 745-751, 2003.

40. Talvensaari-Mattila A, Pääkkö P and Turpeenniemi-Hujanen T: Matrix metalloproteinase-2 (MMP-2) is associated with survival in breast carcinoma. Br J Cancer 89: 1270-1275, 2003

41. Grünwald B, Vandooren J, Gerg M, Ahomaa K, Hunger A, Berchtold S, Akbareian S, Schaten S, Knolle P, Edwards DR, et al: Systemic ablation of MMP-9 triggers invasive growth and metastasis of pancreatic cancer via deregulation of IL6 expression in the bone marrow. Mol Cancer Res 14: 1147-1158, 2016 
42. Roy R, Yang J and Moses MA: Matrix metalloproteinases as novel biomarkers and potential therapeutic targets in human cancer. J Clin Oncol 27: 5287-5297, 2009.

43. Hu R, Zhai Q, Liu W and Liu X: An insight into the mechanism of cytotoxicity of ricin to hepatoma cell: Roles of Bcl-2 family proteins, caspases, $\mathrm{Ca}(2+)$-dependent proteases and protein kinase C. J Cell Biochem 81: 583-593, 2001.

44. Sandur SK, Ichikawa H, Sethi G, Ahn KS and Aggarwal BB Plumbagin (5-hydroxy-2-methyl-1,4-naphthoquinone) suppresses NF-kappaB activation and NF-kappaB-regulated gene products through modulation of p65 and IkappaBalpha kinase activation, leading to potentiation of apoptosis induced by cytokine and chemotherapeutic agents. J Biol Chem 281: 17023-17033, 2006.

45. Tarte K, Jourdan M, Veyrune JL, Berberich I, Fiol G, Redal N, Shaughnessy J Jr and Klein B: The Bcl-2 family member $\mathrm{Bfl}-1 / \mathrm{A} 1$ is strongly repressed in normal and malignant plasma cells but is a potent anti-apoptotic factor for myeloma cells. Br J Haematol 125: 373-382, 2004.

46. Grumont RJ, Rourke IJ and Gerondakis S: Rel-dependent induction of $\mathrm{A} 1$ transcription is required to protect $\mathrm{B}$ cells from antigen receptor ligation-induced apoptosis. Genes Dev 13: 400-411, 1999.

47. Mödder UI, Oursler MJ, Khosla S and Monroe DG: Wnt10b activates the Wnt, notch, and NFKB pathways in U2OS osteosarcoma cells. J Cell Biochem 112: 1392-1402, 2011.

48. Westhoff MA, Zhou S, Nonnenmacher L, Karpel-Massler G, Jennewein C, Schneider M, Halatsch ME, Carragher NO, Baumann B, Krause A, et al: Inhibition of NF- $\kappa \mathrm{B}$ signaling ablates the invasive phenotype of glioblastoma. Mol Cancer Res 11: 1611-1623, 2013.

49. Iyer SV, Ranjan A, Elias HK, Parrales A, Sasaki H, Roy BC, Umar S, Tawfik OW and Iwakuma T: Genome-wide RNA screening identifies TMIGD3 isoform1 as a suppressor of NF- $\kappa \mathrm{B}$ and osteosarcoma progression. Nat Commun 7: 13561, 2016.
50. Jiang C, Fang X, Zhang H, Wang X, Li M, Jiang W, Tian F, Zhu L and Bian Z: AMD3100 combined with triptolide inhibit proliferation, invasion and metastasis and induce apoptosis of human U2OS osteosarcoma cells. Biomed Pharmacother 86: 677-685, 2017.

51. Li CT, Lin CH, Kao TY, Wu MF, Yeh CS, Yeh KT and Ko JL: The mechanisms of action of Tianhua $\left({ }^{\mathrm{TM}}\right)$ on antitumor activity in lung cancer cells. Pharm Biol 48: 1302-1309, 2010.

52. Li M, Li X and Li JC: Possible mechanisms of trichosanthininduced apoptosis of tumor cells. Anat Rec (Hoboken) 293: 986-992, 2010.

53. Mukhopadhyay S, Panda PK, Das DN, Sinha N, Behera B, Maiti TK and Bhutia SK: Abrus agglutinin suppresses human hepatocellular carcinoma in vitro and in vivo by inducing caspase-mediated cell death. Acta Pharmacol Sin 35: 814-824, 2014.

54. Khil LY, Kim W, Lyu S, Park WB, Yoon JW and Jun HS: Mechanisms involved in Korean mistletoe lectin-induced apoptosis of cancer cells. World J Gastroenterol 13: 2811-2818, 2007.

55. Karin M: Nuclear factor-kappaB in cancer development and progression. Nature 441: 431-436, 2006.

This work is licensed under a Creative Commons Attribution-NonCommercial-NoDerivatives 4.0 International (CC BY-NC-ND 4.0) License. 